\title{
Long-Term Investigation and Health Risk Assessment of Multi-class Fungicide Residues in Fruits
}

\author{
Bozena Lozowicka*, Izabela Hrynko, Piotr Kaczynski, \\ Magdalena Jankowska, Ewa Rutkowska \\ Plant Protection Institute - National Research Institute, Laboratory of Pesticide Residues, \\ Chelmonskiego 22, 15-195 Bialystok, Poland
}

Received: 15 October 2015

Accepted: 23 December 2015

\begin{abstract}
Fungicides are chemicals designed against fungi that are widely used in protection of fruits all over the world, for better quality and safety. These chemicals have been intensively used to protect Polish fruits for many years. The objective of this paper was to evaluate the fungicide residues monitored by chromatography and spectrophotometry in fruits in 2005-14 and health risk assessment. Fruits (974 samples) were analyzed for the presence of over 70 fungicides. Currants (68.5\% of samples), apples (63.3\%), and cherries $(54.6 \%)$ were the fruits with residues found most frequently. Dithiocarbamates $(27.4 \%)$ and captan $(26.3 \%)$ were the most often detected. The highest concentrations were noted for boscalid and captan, ranging from $2.83 \mathrm{mg} / \mathrm{kg}$ (cherry) to $3.31 \mathrm{mg} / \mathrm{kg}$ (currant). The risk assessments involving hazards for human health were performed because of fungicide toxicity. The results of this investigation show how important it is to control fungicide residues in fruit, which require frequent chemical treatment for fungal diseases, to guarantee food quality and safety.
\end{abstract}

Keywords: fungicide residues, fruits, risk assessment, GC/ECD/NPD, HPLC/DAD/FLD, LC/MS/MS

\section{Introduction}

Fruits are unquestionably a rich source of vitamins, minerals, and dietary fiber, excellently assimilated by the human organism due to a "natural" manner of application. The demand for fruits systematically increases, and this phenomenon is surely impacted by increasingly greater interest in good nutrition and promotion of a healthy, balanced diet. Fruits are consumed in raw [1] or processed

*e-mail: B.Lozowicka@iorpib.poznan.pl form, e.g., yogurts, kissels, jams, juices, marmalade, or ice cream [2].

According to 2014 data from the Agricultural Market Agency (ARR), Poland is an important fruit producer in Europe. Cherry, currant, raspberry, and apple production and export rank below Italy, Spain, and France, but above Greece and Germany. Poland is also a significant producer of strawberries, gooseberries, and chokeberries [3].

The durability period and nutritional values of fruits are determined by fungal diseases and chemical pollution caused by pesticides [4]. The most common fungal diseases attacking fruit include powdery mildew, 
Table 1. Analysed active substances and their substance groups.

\begin{tabular}{|c|c|c|c|c|c|}
\hline Substance group & Active substances & Substance group & $\begin{array}{c}\text { Active } \\
\text { substances }\end{array}$ & $\begin{array}{l}\text { Substance } \\
\text { group }\end{array}$ & $\begin{array}{c}\text { Active } \\
\text { substances }\end{array}$ \\
\hline $\begin{array}{l}\text { Acylamino acid } \\
\text { (Group 1) }\end{array}$ & benalaxyl $1^{3,4}$ & $\begin{array}{l}\text { Imidazole } \\
\text { (Group 15) }\end{array}$ & $\begin{array}{l}\text { prochloraz }^{3,4} \\
\text { imazalil }^{3,4}\end{array}$ & \multirow{3}{*}{$\begin{array}{l}\text { Strobilurin } \\
\text { (Group 29) }\end{array}$} & \multirow{3}{*}{$\begin{array}{l}\text { azoxystrobin }^{3,4} \\
\text { dimoxystrobin }^{3,4} \\
\text { kresoxim-methyl } \\
\text { pyraclostrobin }^{3,4} \\
\text { picoxystrobin } \\
\text { trifloxystrobin }\end{array}$} \\
\hline $\begin{array}{c}\text { Amine } \\
\text { (Group 2) }\end{array}$ & diphenylamine $^{3}$ & $\begin{array}{l}\text { Morpholine } \\
\text { (Group 16) }\end{array}$ & $\begin{array}{l}\text { dimethomorph } \\
\text { fenpropimorph }^{3,4} \\
\end{array}$ & & \\
\hline $\begin{array}{l}\text { Anilinopyrimidine } \\
\text { (Group 3) }\end{array}$ & $\begin{array}{c}\text { cyprodinil }^{3,4} \\
\text { mepanipyrim }^{3,4} \\
\text { pyrimethanil }^{3,4}\end{array}$ & $\begin{array}{l}\text { Oxazolidin } \\
\text { (Group 17) }\end{array}$ & chlozolinate $^{3}$ & & \\
\hline $\begin{array}{l}\text { Benzamide } \\
\text { (Group 4) }\end{array}$ & $\begin{array}{c}\text { zoxamide }^{3,4} \\
\text { fluopicolide }^{3,4}\end{array}$ & $\begin{array}{c}\text { Oxazole } \\
\text { (Group 18) }\end{array}$ & $\begin{array}{l}\text { famoxadone } \\
\text { vinclozolin } \\
\text { vi,4 }\end{array}$ & $\begin{array}{l}\text { Strobilurin } \\
\text { (Group 30) }\end{array}$ & bensulfuron-methyl ${ }^{4}$ \\
\hline $\begin{array}{l}\text { Benzimidazole } \\
\text { (Group 5) }\end{array}$ & $\begin{array}{l}\text { carbendazim }^{2,4} \\
\text { thiabendazole } \\
\text { thi, }\end{array}$ & $\begin{array}{l}\text { Quinoline } \\
\text { (Group 19) }\end{array}$ & qinoxyfen ${ }^{3,4}$ & \multirow{10}{*}{$\begin{array}{c}\text { Triazole } \\
\text { (Group 31) }\end{array}$} & \multirow{10}{*}{$\begin{array}{c}\text { azaconazole } \\
\text { bitertanol }{ }^{3,4} \\
\text { bromuconazole } \\
\text { cyproconazole }^{3,4} \\
\text { difenoconazole } \\
\text { diniconazole }^{3,4} \\
\text { epoxiconazole }^{3,4} \\
\text { fenbuconazole } \\
\text { flusilazole } \\
\text { flutriafol }{ }^{3,4} \\
\text { fluquinconazole } \\
\text { hexaconazole } \\
\text { imibenconazole } \\
\text { metconazole } \\
\text { myclobutanil }^{3,4} \\
\text { paclobutrazol }^{3,4} \\
\text { penconazole }^{3,4} \\
\text { propiconazole }^{3,4} \\
\text { prothioconazole- }^{3} \\
\text { desthio }^{3,4} \\
\text { tebuconazole } \\
\text { tetraconazole } \\
\text { triticonazole }^{3,4} \\
\text { triadimenol }^{3,4} \\
\text { triadimefon }^{3,4}\end{array}$} \\
\hline $\begin{array}{c}\text { Benzophenone } \\
\text { (Group 6) }\end{array}$ & metrafenone $e^{3,4}$ & $\begin{array}{c}\text { Oxathiin } \\
\text { (Group 20) }\end{array}$ & flutolanil ${ }^{3,4}$ & & \\
\hline $\begin{array}{l}\text { Carbamate } \\
\text { (Group 7) }\end{array}$ & $\begin{array}{c}\text { bendiocarb }^{4} \\
\text { benfuracarb }^{4} \\
\text { dithiocarbamates*1 } \\
\text { iprovalicarb } \\
\end{array}$ & $\begin{array}{l}\text { Pyrimidine } \\
\text { (Group 21) }\end{array}$ & fenarimol ${ }^{3,4}$ & & \\
\hline $\begin{array}{l}\text { Carboxamide } \\
\text { (Group 8) }\end{array}$ & boscalid $^{3,4}$ & $\begin{array}{l}\text { Phthalimide } \\
\text { (Group 22) }\end{array}$ & $\begin{array}{c}\text { captafol }^{3,4} \\
\text { captan }^{3} \\
\text { folpet }^{3,4}\end{array}$ & & \\
\hline $\begin{array}{l}\text { Conazole } \\
\text { (Group 9) }\end{array}$ & etaconazole $\mathrm{e}^{3,4}$ & $\begin{array}{l}\text { Phenylamide } \\
\text { (Group 23) }\end{array}$ & $\begin{array}{c}\text { oxadixyl }^{3,4} \\
\text { metalaxyl }^{3,4}\end{array}$ & & \\
\hline $\begin{array}{l}\text { Chloronitrile } \\
\text { (Group 10) }\end{array}$ & chlorothalonil $^{3}$ & $\begin{array}{c}\text { Phenylpyrrole } \\
\text { (Group 24) }\end{array}$ & fludioxonil ${ }^{3,4}$ & & \\
\hline $\begin{array}{l}\text { Chlorinated } \\
\text { hydrocarbon } \\
\text { (Group 11) }\end{array}$ & $\mathrm{HCB}^{3}$ & $\begin{array}{l}\text { Phenylurea } \\
\text { (Group 25) }\end{array}$ & pencycuron $^{3,4}$ & & \\
\hline $\begin{array}{l}\text { Chlorophenyl } \\
\text { (Group 12) }\end{array}$ & $\begin{array}{c}\text { dicloran }^{3} \\
\text { tolclofos-methyl } \\
\text { tecnazene } \\
\text { quintozene } \\
\text { (3) }\end{array}$ & $\begin{array}{l}\text { Pyrimidinol } \\
\text { (Group 26) }\end{array}$ & bupirimate ${ }^{3,4}$ & & \\
\hline $\begin{array}{l}\text { Dicarboximide } \\
\text { (Group 13) }\end{array}$ & $\begin{array}{c}\text { iprodione } \\
\text { procymidone } \\
\text { procy }^{3,4}\end{array}$ & $\begin{array}{l}\text { Phosphorothiolate } \\
\text { (Group 27) }\end{array}$ & $\begin{array}{c}\text { pyrazophos }^{3,4} \\
\text { isoprothiolane } \\
\text { is,4 }\end{array}$ & & \\
\hline $\begin{array}{l}\text { Hydroxyanilide } \\
\text { (Group 14) }\end{array}$ & fenhexamid ${ }^{3,4}$ & $\begin{array}{l}\text { Sulphamide } \\
\text { (Group 28) }\end{array}$ & $\begin{array}{l}\text { tolylfluanid }^{3,4} \\
\text { dichlofluanid }^{3,4}\end{array}$ & & \\
\hline
\end{tabular}

*determined as $\mathrm{CS}_{2}$ residues

${ }^{1}$ spectrophotometric, ${ }^{2} \mathrm{HPLC} / \mathrm{DAD} / \mathrm{FLD},{ }^{3} \mathrm{GC} / \mathrm{ECD} / \mathrm{NPD},{ }^{4} \mathrm{LC} / \mathrm{MS} / \mathrm{MS}$

responsible for the destruction of grapes [5]. Powdery mildew is one of the most widespread and dangerous diseases, which can infect all volatile parts of a vine, including leaves, stems, inflorescence, and fruits [6]. Gray mold, caused by Botrytis cinerea, is the most destructive postharvest disease of grapes [7], apples [8], strawberries [9], and peaches [10]. The main harmful effect of gray mold is reduction of the yield and quality of the harvested fruit. In the period of vegetation and fruiting, apple and pear trees are very vulnerable to attacks of the pathogens Venturia inaequalis and Venturia pirina, causing apple scab and pear scab, respectively [11]. In turn, peach leaf curl, caused by the fungus called Taphrina deformans, infects leaves and shoots of peaches and nectarines [12].

To protect fruits against diverse fungal diseases, it is necessary to use plant protection products (p.p.p.) [13].
Fungicides are chemicals designed against fungi, widely used in plant protection all over the world [14], for better quality and safety. These chemicals are intensively used in protection of Polish fruits for many years. Currently, to protect fruit plants from fungal diseases, more than 80 fungicides are registered in Poland [15]. For example, azoxystrobin, kresoxim-methyl, trifloxystrobin, and pyraclostrobin (strobilurin fungicides) are used to treat grape powdery mildew [16]. Phenylpyrrole (e.g., fludioxonil), anilinopyrimidine (e.g., pyrimethanil) [17], and carboxamide (e.g., boscalid fungicides) are used to control gray mold.

Despite their many merits such as better yields and quality, pesticides are one of the most toxic, stable, and mobile substances in the environment. They may penetrate the tissues of fruits and appear in the pulp and juice of fruits 
[18]. Widespread use of pesticides from various chemical groups, characterized by different mechanisms, may pose a hazard to human health and the natural environment due to their toxicity, high persistence, and bioaccumulation [19]. Pesticide residues in fruits, depending on significant properties of their active ingredients, may cause many adverse side effects, from allergies to chronic diseases and cancer [20].

The objective of this paper was to evaluate multiclass fungicide residues in Polish fruits in 2005-14 using spectrophotometric and chromatographic techniques (GC/ ECD/NPD, HPLC/DAD/FLD, LC/MS/MS) and health risk assessment. Because of fungicide toxicity, the results of this investigation show how important it is to control these pesticides, in particular, in fruit requiring frequent chemical treatment for fungal diseases, to guaranty food quality and consumer safety.

\section{Materials and Methods}

\section{Samples}

In the framework of the official testing of residues of plant protection products conducted by the Ministry of Agriculture and Rural Development, in total 974 samples of fruits (nuts, berries, pome, and stone fruits) were analyzed at the Official Laboratory of Pesticide Residue in Bialystok, Poland (53 $139^{\prime} \mathrm{N}$ latitude and $23^{\circ} 159^{\prime} \mathrm{E}$ longitude). These samples were collected from May 2005 to November 2014 by the regional inspectors of plant protection and seed according to a predetermined schedule. Raw fruit samples were subjected to the analytical procedures described below.

\section{Chemicals and Reagents}

All reagents were analytical grade. Fungicides (77 active substances) were obtained from Dr. Ehrenstorfer Laboratory (Germany). Standard stock solutions (purity for all standards $>95 \%$ ) of various concentrations were prepared in acetone and stored in dark glass bottles below $4^{\circ} \mathrm{C}$.

Pesticides (Table 1) belonging to fungicides from various groups in terms of chemical structure, e.g., anilinopyrimidine, benzimidazole, carboxamide, dicarboximide, phthalimide, strobilurin, sulphamide, triazole, and carbamate (31 groups), were analyzed.

\section{Analytical Procedure}

We used four methods for sample preparation as described in our earlier work [21-22]: two multi-residue methods (MRM) and two single residue methods (SRM) (Fig. 1).

\section{Single Residue Method:}

- Isolation and determination of dithiocarbamates (DTC) using spectrophotometry.
Dithiocarbamate residues were determined as a group (mancozeb, maneb, methiram, propineb, thiram, ziram) by a spectrophotometric method and expressed as carbon disulphide. Fifty grams of sample with $60 \mathrm{~mL}$ of hydrochloric acid (4 M) and tin (II) chloride $(0.13 \mathrm{M})$ was heated for 45 minutes (temperature about $80^{\circ} \mathrm{C}$ ) to release carbon disulphide from dithiocarbamates to obtain $\mathrm{pH}$ between 11-12.

Carbon disulphide was separated and collected in a methanolic solution of potassium hydroxide, forming potassium xantogenate, which was next heated with zinc acetate to obtain zinc sulfide. Finally, the quantity of the formed complex (final volume $25 \mathrm{~mL}$ ) was estimated and the absorbance at a wavelength of $662 \mathrm{~nm}$ on a spectrophotometer was measured (Helios Delta VIS and Nidet Evolution 220 LC).

- Isolation and determination of carbendazim residues using high-performance liquid chromatography (HPLC).

A representative sample of $20 \mathrm{~g}$ of $150 \mathrm{~mL}$ acetone was homogenized for $5 \mathrm{~min}$. Then $2.5 \mathrm{~g}$ of celite was added and filtered through a Buchner funnel. The final filtrate was evaporated in a rotary evaporator, leaving about $20 \mathrm{~mL}$. Then this solution was applied to a ChemElut cartridge containing diatomaceous earth. After $25 \mathrm{~min}$ of equilibration, the pesticides were eluted with dichloromethane. The organic solvent was evaporated to dryness using a rotary vacuum evaporator at $40^{\circ} \mathrm{C}$ and dissolved in a $2 \mathrm{~mL}$ volume of a mixture of acetonitrile/ water $(2: 8, \mathrm{v} / \mathrm{v})$. The extracts were analyzed with liquid chromatography (Waters Alliance 2695 chromatograph) with simultaneous use of a diode array detector (Waters 2996) at $285 \mathrm{~nm}$ and fluorescence detector (Waters 2475) $\left(\lambda_{\text {ex }}=285 \mathrm{~nm}, \lambda_{\text {em }}=315 \mathrm{~nm}\right)$. The external standard method was used, by applying $100 \mu \mathrm{L}$ of standard solution on the column (Supelcosil LC-18, $5 \mu \mathrm{m}, 250 \times 4.6 \mathrm{~mm}$ ). The mobile phase was acetonitrile-phosphate buffer $\mathrm{pH}=8$, delivered at a flow rate of $0.8 \mathrm{ml} / \mathrm{min}$, with a gradient composition consisting of $20 \%$ (v/v) acetonitrile for $2 \mathrm{~min}$, a linear increase over $13 \mathrm{~min}$ to $50 \%$ acetonitrile, then an increase to $80 \%$ acetonitrile over $5 \mathrm{~min}$, and finally a decrease at $20 \%$ acetonitrile over $5 \mathrm{~min}$.

\section{Multi-residue methods:}

- Isolation and determination of fungicide residues using matrix solid phase disepersion (MSPD) and gas chromatography with a dual detection system (GC/ ECD/NPD).

Two grams of homogenized sample was put in a mortar and manually blended with $4 \mathrm{~g}$ of solid support using a pestle to obtain a homogeneous mixture, and then quantitatively transferred with a spatula to a glass macro column packed with anhydrous sodium sulfate $(5.0 \mathrm{~g})$ and silica gel $(2.5 \mathrm{~g})$. Depending on the commodity, either silica gel (strawberries, raspberries, plums, grapes, peaches) or florisil (apples, currants, gooseberries, blueberries, sour cherries, sweet cherries, pears) was used. The analytes were eluted using $15 \mathrm{~mL}$ hexane/acetone $(8: 2, \mathrm{v} / \mathrm{v})$ and $15 \mathrm{~mL}$ hexane/diethyl 
Table 2. Optimised MRM transitions by direct ESI source infusion.

\begin{tabular}{|c|c|c|c|c|c|c|c|c|c|}
\hline Pesticide & $\begin{array}{l}\text { MRM transition, } \\
\mathrm{m} / \mathrm{z}\end{array}$ & $\begin{array}{l}\text { DP } \\
(V)\end{array}$ & $\begin{array}{l}\text { CE } \\
(V)\end{array}$ & $\begin{array}{l}\text { CXP } \\
(\mathrm{V})\end{array}$ & Pesticide & $\begin{array}{l}\text { MRM transition, } \\
\mathrm{m} / \mathrm{z}\end{array}$ & $\begin{array}{l}\text { DP } \\
(V)\end{array}$ & $\begin{array}{l}\text { CE } \\
(V)\end{array}$ & $\begin{array}{l}\text { CXP } \\
\text { (V) }\end{array}$ \\
\hline \multirow[t]{2}{*}{ Azaconazole } & $300>159$ & 86 & 37 & 10 & Iprodione & $330.1>244.9$ & 61 & 21 & 14 \\
\hline & $300>231$ & 86 & 23 & 12 & & $330.1>101$ & 61 & 37 & 6 \\
\hline \multirow[t]{2}{*}{ Azoxystrobin } & $404.1>371.9$ & 61 & 19 & 20 & Iprovalicarb & $321.2>119.1$ & 61 & 23 & 8 \\
\hline & $404.1>344$ & 61 & 33 & 18 & & $321.2>203.2$ & 61 & 12 & 10 \\
\hline \multirow[t]{2}{*}{ Benalaxyl } & $326.1>148.1$ & 76 & 27 & 8 & Isoprothiolane & $291>231$ & 21 & 15 & 12 \\
\hline & $326.1>208.2$ & 76 & 21 & 12 & & $291>188.9$ & 21 & 29 & 10 \\
\hline \multirow[t]{2}{*}{ Bendiocarb } & $224.11>167.1$ & 36 & 13 & 10 & Kresoxim-methyl & $314.1>206$ & 70 & 10 & 10 \\
\hline & $224.11>109$ & 36 & 23 & 8 & & $314.1>116.1$ & 70 & 19 & 8 \\
\hline \multirow[t]{2}{*}{ Benfuracarb } & $411.2>195.1$ & 66 & 28 & 10 & Mepanipyrim & $224>106$ & 131 & 33 & 18 \\
\hline & $411.2>89.9$ & 66 & 21 & 10 & & $224>66$ & 131 & 59 & 10 \\
\hline \multirow[t]{2}{*}{$\begin{array}{c}\text { Bensulfuron- } \\
\text { methyl }\end{array}$} & $411>149$ & 101 & 27 & 8 & Metalaxyl & $280.1>220.1$ & 41 & 19 & 12 \\
\hline & $411>118.9$ & 101 & 57 & 12 & & $280.1>160.1$ & 41 & 31 & 10 \\
\hline \multirow[t]{2}{*}{ Bitertanol } & $338>269$ & 50 & 15 & 16 & Metconazole & $320.1>70$ & 56 & 63 & 8 \\
\hline & $338>70$ & 50 & 25 & 16 & & $320.1>124.9$ & 56 & 55 & 6 \\
\hline \multirow[t]{2}{*}{ Boscalid } & $343>307$ & 116 & 27 & 16 & Metrafenone & $409>209$ & 61 & 19 & 12 \\
\hline & $343>140$ & 116 & 25 & 8 & & $409>226.9$ & 61 & 27 & 12 \\
\hline \multirow[t]{2}{*}{ Bromuconazole } & $378>159$ & 91 & 35 & 10 & Myclobutanil & $289>70$ & 71 & 23 & 8 \\
\hline & $378>70$ & 91 & 61 & 8 & & $289>125$ & 71 & 45 & 8 \\
\hline \multirow[t]{2}{*}{ Bupirimate } & $317.1>166.1$ & 91 & 31 & 10 & Oxadixyl & $279.1>219.1$ & 46 & 15 & 12 \\
\hline & $317.1>108.1$ & 91 & 33 & 8 & & $279.1>133.1$ & 46 & 29 & 8 \\
\hline \multirow[t]{2}{*}{ Captafol } & $350>313.9$ & 76 & 17 & 4 & Paclobutrazol & $294>70$ & 66 & 51 & 10 \\
\hline & $350>312$ & 76 & 17 & 4 & & $294>125.1$ & 66 & 49 & 8 \\
\hline \multirow[t]{2}{*}{ Carbendazim } & $192>160.1$ & 71 & 27 & 10 & Penconazole & $284>70$ & 56 & 21 & 8 \\
\hline & $192>132.1$ & 71 & 43 & 8 & & $284>158.9$ & 56 & 35 & 8 \\
\hline \multirow[t]{2}{*}{ Cyproconazole } & $292>70$ & 61 & 23 & 8 & Pencycuron & $329>124.9$ & 70 & 29 & 6 \\
\hline & $292>125$ & 61 & 45 & 6 & & $331>126.9$ & 70 & 31 & 6 \\
\hline \multirow[t]{2}{*}{ Cyprodinil } & $226.1>93$ & 71 & 43 & 12 & Picoxystrobin & $368>205$ & 36 & 13 & 12 \\
\hline & $226.1>77$ & 71 & 61 & 12 & & $368>145$ & 36 & 29 & 8 \\
\hline \multirow[t]{2}{*}{ Dichlofluanid } & $350>223.9$ & 60 & 21 & 12 & Prochloraz & $376>307.9$ & 16 & 17 & 16 \\
\hline & $350>123$ & 60 & 39 & 6 & & $376>70$ & 16 & 29 & 10 \\
\hline \multirow[t]{2}{*}{ Difenoconazole } & $406>251$ & 96 & 35 & 14 & Procymidone & $284.1>256$ & 50 & 23 & 14 \\
\hline & $406>188$ & 96 & 59 & 10 & & $284.1>67$ & 50 & 50 & 8 \\
\hline \multirow[t]{2}{*}{ Dimethomorph } & $388.1>301$ & 36 & 29 & 16 & Propiconazole & $342>159$ & 100 & 37 & 10 \\
\hline & $388.1>165.1$ & 36 & 41 & 10 & & $342>69$ & 100 & 23 & 8 \\
\hline \multirow[t]{2}{*}{ Dimoxystrobin } & $327>205$ & 61 & 15 & 12 & $\begin{array}{l}\text { Prothioconazol- } \\
\text { desthio }\end{array}$ & $312>69.9$ & 96 & 61 & 8 \\
\hline & $327>116.1$ & 61 & 29 & 6 & & $312>125$ & 96 & 37 & 6 \\
\hline \multirow[t]{2}{*}{ Diniconazole } & $326.1>70.1$ & 25 & 63 & 8 & Pyraclostrobin & $388>194.1$ & 41 & 17 & 12 \\
\hline & $326.1>158.9$ & 25 & 39 & 10 & & $388>163.1$ & 41 & 33 & 10 \\
\hline
\end{tabular}


Continued

\begin{tabular}{|c|c|c|c|c|c|c|c|c|c|}
\hline Etaconazole & $328.1>159$ & 61 & 37 & 10 & Pyrazofos & $374>222$ & 81 & 29 & 7 \\
\hline & $328.1>123$ & 61 & 75 & 6 & & $374>194$ & 81 & 43 & 5 \\
\hline \multirow[t]{2}{*}{ Famoxadon } & $392.1>331.1$ & 50 & 11 & 18 & Pyrimethanil & $200.1>107$ & 96 & 33 & 12 \\
\hline & $392.1>238.1$ & 50 & 23 & 14 & & $200.1>82$ & 96 & 32 & 9 \\
\hline \multirow[t]{2}{*}{ Fenarimol } & $331.1>268$ & 70 & 31 & 14 & Qinoxyfen & $308>196.9$ & 46 & 43 & 10 \\
\hline & $331.1>81$ & 70 & 35 & 16 & & $308>162$ & 46 & 59 & 8 \\
\hline \multirow[t]{2}{*}{ Fenbuconazole } & $337>125.1$ & 96 & 35 & 8 & Tebuconazol & $308.1>70$ & 41 & 57 & 8 \\
\hline & $337>70$ & 96 & 23 & 8 & & $308.1>125.1$ & 41 & 59 & 8 \\
\hline \multirow[t]{2}{*}{ Fenhexamid } & $302.1>97.1$ & 86 & 31 & 6 & Tetraconazole & $372>159$ & 26 & 37 & 10 \\
\hline & $302.1>55$ & 86 & 57 & 8 & & $372>70$ & 26 & 73 & 10 \\
\hline \multirow[t]{2}{*}{ Fenpropimorph } & $304.2>147.1$ & 91 & 39 & 8 & Thiabendazol & $202>175$ & 121 & 37 & 10 \\
\hline & $304.2>117.1$ & 91 & 77 & 8 & & $202>131.1$ & 121 & 45 & 8 \\
\hline \multirow[t]{2}{*}{ Fludioxonil } & $266.1>229$ & 65 & 17 & 12 & Tolclofos-methyl & $301>268.9$ & 61 & 23 & 14 \\
\hline & $266.1>157.9$ & 65 & 45 & 8 & & $301>174.9$ & 61 & 35 & 10 \\
\hline \multirow[t]{2}{*}{ Fluopicolid } & $383>172.9$ & 91 & 31 & 10 & Tolylfluanid & $364>238$ & 100 & 19 & 12 \\
\hline & $383>108.9$ & 91 & 89 & 6 & & $364>137$ & 100 & 39 & 8 \\
\hline \multirow[t]{2}{*}{ Flusilazole } & $316.1>247$ & 26 & 25 & 14 & Triadimefon & $294.1>197.1$ & 51 & 21 & 12 \\
\hline & $316.1>165.1$ & 26 & 35 & 10 & & $294.1>225$ & 51 & 17 & 11 \\
\hline \multirow[t]{2}{*}{ Flutolanil } & $324.1>262$ & 16 & 25 & 14 & Triadimenol & $296>70$ & 56 & 19 & 8 \\
\hline & $324.1>242$ & 16 & 35 & 14 & & $296>227$ & 56 & 15 & 8 \\
\hline \multirow[t]{2}{*}{ Flutriafol } & $302>123$ & 61 & 37 & 6 & Trifloxystrobin & $409.1>186$ & 61 & 25 & 10 \\
\hline & $302>109$ & 61 & 37 & 5 & & $409.1>206.1$ & 61 & 19 & 12 \\
\hline \multirow[t]{2}{*}{ Folpet } & $315>130$ & 50 & 39 & 6 & Triticonazole & $318>70$ & 71 & 49 & 8 \\
\hline & $315>163$ & 50 & 19 & 7 & & $318>125$ & 71 & 47 & 8 \\
\hline \multirow[t]{2}{*}{ Hexaconazole } & $314.1>70$ & 21 & 49 & 8 & Vinclozolin & $286>214$ & 76 & 17 & 12 \\
\hline & $314.1>159$ & 21 & 37 & 10 & & $286>174$ & 76 & 45 & 10 \\
\hline \multirow[t]{2}{*}{ Imazalil } & $297>159$ & 81 & 31 & 10 & Zoxamide & $336.1>186.9$ & 46 & 31 & 10 \\
\hline & $297>201$ & 81 & 23 & 10 & & $336.1>159$ & 46 & 55 & 10 \\
\hline
\end{tabular}

DP-declustering potential; CE-collision energy; CXP-collision cell exit potential

ether/acetone $(1: 2: 2, \mathrm{v} / \mathrm{v} / \mathrm{v})$. The extract was evaporated to dryness using a rotary vacuum evaporator at about $40^{\circ} \mathrm{C}$. Then the eluate was re-dissolved using $2 \mathrm{~mL}$ of hexane/acetone $(9: 1, \mathrm{v} / \mathrm{v})$. The fruit samples by an Agilent (Waldbronn, Germany) model 7890A gas chromatograph equipped with EC and NP detectors were analyzed. A capillary column HP-5 (5 \%-phenylmethylpolysiloxane) $(30 \mathrm{~m} \times 0.32 \mathrm{~mm}, 0.5 \mu \mathrm{m}$ film thickness) and for confirmation of residues a mid-polarity column HP-35 ((35\%-Phenyl)-methylpolysiloxane $(30 \mathrm{~m} \times 0.32 \mathrm{~mm}, 0.5$ $\mu \mathrm{m}$ film thickness) were used. The injector and detectors temperature were set at 210 and $300^{\circ} \mathrm{C}$, respectively. The oven temperature was programmed as follows: 120 to $190^{\circ} \mathrm{C}$ at a rate of $16^{\circ} \mathrm{C} \mathrm{min}^{-1}$, increased to $230^{\circ} \mathrm{C}$ at $8^{\circ} \mathrm{C}$ $\min ^{-1}$, and then to $285^{\circ} \mathrm{C}$ at $18^{\circ} \mathrm{C} \mathrm{min}^{-1}$, for $18 \mathrm{~min}$. Helium (purity 5.0) was used as a carrier gas at a flow rate of $3.0 \mathrm{ml} \mathrm{m^{-1 }}$. Nitrogen (purity 5.0) as a makeup gas was used for EC, and NP detectors were set at 57 and $8 \mathrm{ml} \mathrm{min}-1$, respectively. The air (purity 5.0) and hydrogen (purity 5.0) (for NPD) gas flows were set at 60 and

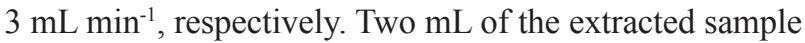
solution was injected.

- Isolation and determination of fungicide residues using QuEChERS and liquid chromatography (LC-MS/MS).

Ten grams of homogenized fruit sample were weighted in a $50 \mathrm{~mL}$ polypropylene centrifuge tube. The sample was extracted with $10 \mathrm{~mL}$ of acetonitrile and shaken vigorously 
for $1 \mathrm{~min}$ and vortexed for $1 \mathrm{~min}$ using a digital VortexMixer (Velp Scientifica, Usmate, Italy). Next, 4 g MgSO, $1 \mathrm{~g} \mathrm{NaCl}, 1 \mathrm{~g}$ trisodium citrate dehydrate, and $0.5 \mathrm{~g}$ disodium hydrogen citrate sesquehydrate were added. The tubes were immediately shaken for $1 \mathrm{~min}$, vortexed in a Vortex-Mixer for $1 \mathrm{~min}$, and then centrifuged for $5 \mathrm{~min}$ at $4,500 \mathrm{rpm}$. Acetonitrile extract was transferred into $15 \mathrm{~mL}$ tubes containing $150 \mathrm{mg}$ anhydrous $\mathrm{MgSO}_{4}$. Depending on the commodity, either $25 \mathrm{mg}$ PSA (gooseberries, sweet cherries, pears, apples, plums, strawberries, grapes) or $25 \mathrm{mg}$ PSA and $2.5 \mathrm{~g}$ GBC (raspberries, blueberries, blueberries) was used. The tubes were vortexed for $1 \mathrm{~min}$ and centrifuged at 4,500 rpm for $10 \mathrm{~min}$. One $\mathrm{ml}$ of the final extract was filtered through a $0.2 \mathrm{~m}$ hydrophilic PTFE filter, transferred into the appropriately labeled autosampler vial, and subsequently analyzed via LC-MS/MS. An Eksigent Ultra LC-100 (Eksigent Technologies, Dublin, CA, USA) liquid chromatography system operated at a flow rate of $0.45 \mathrm{ml} \mathrm{min}{ }^{-1}$ without split using a SunFire $\mathrm{C}_{18} 3.5 \mu \mathrm{m}$, $2.1 \times 100 \mathrm{~mm}$ (Waters) analytical column, maintained at $50^{\circ} \mathrm{C}$ during the experiments. The volume injected into the LC-MS/MS system was $10 \mu \mathrm{L}$. The binary mobile phase consisted of water with $0.5 \%$ formic acid and $5 \mathrm{mM}$ ammonium formate (phase A) and methanol with $0.5 \%$ formic acid and $5 \mathrm{mM}$ ammonium formate (phase B). The initial composition of $95 \% \mathrm{~A}$ and $5 \% \mathrm{~B}(\mathrm{v} / \mathrm{v})$ was held for $2.0 \mathrm{~min}$., followed by linear ramping to $95 \%$ of B in $8 \mathrm{~min}$. and was held for $7 \mathrm{~min}$. After ramping, the mobile phase returned to the initial composition in 2 minutes. The total chromatographic run time was $25.0 \mathrm{~min}$. System MS/MS 6,500 QTRAP (AB Sciex Instruments, Foster City, CA) was used for mass spectrometric analysis, equipped with an electrospray ionization source (ESI). The capillary voltage was maintained at $4,500 \mathrm{~V}$ for positive ion mode and the temperature of the turbo heaters was set at $450^{\circ} \mathrm{C}$. For the nebulizer gas (GS1), auxiliary gas (GS2), and curtain gas (CUR), nitrogen was used at a pressure of 65 , 45 , and 35 psi, respectively. For the nebulizer and collision gases a nitrogen was used. Optimization of the compounds was performed by injecting individual standard solutions directly into the source (flow injection analysis methods, or FIA) (Table 2).

\section{Validation of Methods}

Validation of the analytical methods was carried out in accordance with European Commission (EC) guidelines. The validation studies were performed using pesticidefree fruit samples. Calibration standards were prepared in the fruit matrix solution to produce a final concentration of spiking concentrations:

- For spectrophotometric: $0.03 \mathrm{mg} / \mathrm{kg}, 0.1 \mathrm{mg} / \mathrm{kg}$ and $5.0 \mathrm{mg} / \mathrm{kg}$;

- For HPLC: $0.02 \mathrm{mg} / \mathrm{kg}, 0.5 \mathrm{mg} / \mathrm{kg}, 2.0 \mathrm{mg} / \mathrm{kg}$;

- For GC: range $0.002-0.05 \mathrm{mg} / \mathrm{kg}$, range $0.05-0.5 \mathrm{mg} /$ $\mathrm{kg}$, and range $0.5-5.0 \mathrm{mg} / \mathrm{kg}$;

- For LC-MS/MS: range $0.005-0.01 \mathrm{mg} / \mathrm{kg}$, range $0.01-0.2 \mathrm{mg} / \mathrm{kg}$, and range $0.2-1.0 \mathrm{mg} / \mathrm{kg}$.

The accuracy and precision of the method were evaluated by performing recovery studies and expressed as relative standard deviation (RSD, \%) and mean recovery, respectively. Repeatability was calculated for five days using five replicates for each level of three different concentration levels.

\section{Quality Check}

The laboratory participates in international proficiency tests organised by the Food Analysis Performance Assessment Scheme (FAPAS; Central Science Laboratory in York) and by the European Commission (University of Almeria) every year, and achieves correct results. All of the analyses were conducted using accredited methods by the Polish Centre of Accreditation (PCA) in compliance with PN-EN ISO/IEC 17025.

\section{Risk Assessment}

The health risk estimation through a comparison of detected fungicide residues with the established Acceptable Daily Intake (ADI) or Acute Reference Dose (ARfD) was calculated. The level of residue concentration in a product was determined as the arithmetic mean of all the results obtained. In the case of results under the limit of detection (LOD) of analytical methods for intake calculations, LOD values were taken. The long- or short-term dietary consumer exposure to pesticide residues was estimated using an EFSA calculation model: Pesticide Residue Intake Model "PRIMo" revision 2. This model is based on national food consumption and unit weights implementing internationally agreed risk assessment methodologies to assess the exposure of consumers, accepting consumption at the level of the 97.5 percentile [23]. Additionally, longterm risk assessment comparing the pesticide toxicological data for groups: cluster E, adults and children, and the Polish general population by calculating the hazard quotient (HQ) was performed. Its value was estimated by dividing the international estimated daily intake with the relevant acceptable daily intake, which was considered to be safe levels of exposure over a lifetime.

\section{Short-Term Risk}

Short-term risk was estimated by comparing single intake of the highest detected residue of plant protection products (HR_P) full portion consumption data for the commodity unit (F) to a set volume ARfD (Acute Reference Dose). The estimated short-term intake (ESTI) was calculated according to the following formula [24]:

$$
\begin{gathered}
\mathrm{ESTI}=(\mathrm{F} \times \text { HR_P }) / \text { mean_body_weight } \\
\text { Long-Term Risk }
\end{gathered}
$$

The acceptable daily intake (ADI) is the estimated amount of a substance in food, expressed on a body weight basis, that can be ingested daily over a lifetime without appreciable chronic, long-term risk to any consumer. The 


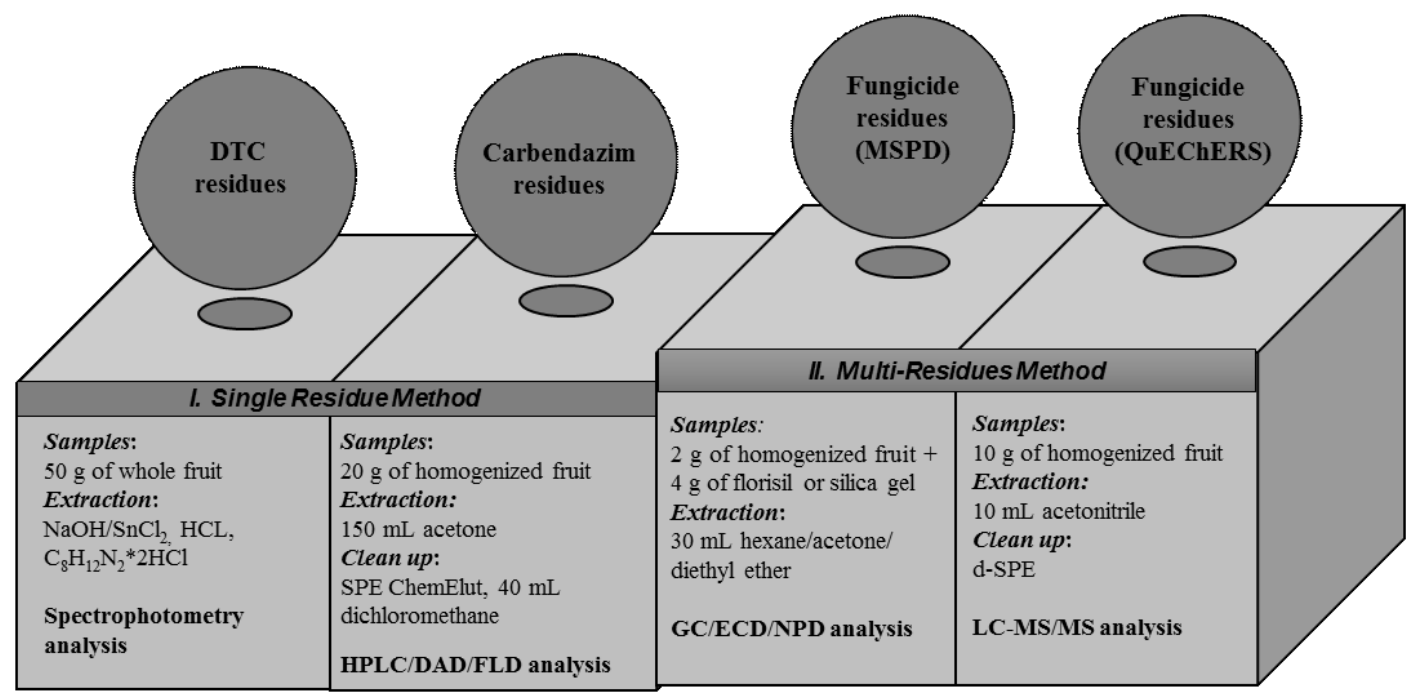

Fig. 1. Scheme of sample preparation procedures.

estimated daily intake (EDI) was calculated according to the following formula, where Fi is food-consumption data and RLi is residue level in the commodity:

$$
\mathrm{EDI}=(\mathrm{Fi} \times \mathrm{RLi}) / \text { mean_body_weight }
$$

The long-term risk was assessed by calculating the hazard quotient (HQ) by dividing the estimated daily intake by the relevant acceptable daily intake:

$$
\mathrm{HQ}=(\mathrm{EDI} / \mathrm{ADI}) \times 100 \%
$$

\section{Results and Discussion}

\section{Analytical Methods and Validation Parameters}

Four methods were used in sample preparation (Fig. 1). Procedure one of two multi-residue methods (MRM) for determination of 73 compounds using gas chromatography with selective detectors: electron capture (EC) and nitorgen phopsphorous (NP) is described [25]. Two single residue method (SRM) for determination of carbendazime using liquid chromatography and dithitocarbamates by spectrophotometric (described in our earlier published work $[22,26])$ were used. LC/MS/MS for determining 66 compounds was performed and validation parameters are presented in Table 3. In 2014 the carbendazime was included in the MRM method and analysed by LC/MS/ MS.

The preparation and analytical methods for fungicide residues in fruit sample were validated in terms of linearity and limits of detection respectively. The limit of quantification (LOQ) and the limit of detection (LOD) were calculated using signal-to-noise ratios $(\mathrm{S} / \mathrm{N})$ of 10:1 and $3: 1$ for the pesticide, respectively. The LOQs ranged from 0.02 to $0.05 \mathrm{mg} / \mathrm{kg}$ (for spectrophotometric), 0.01 to $0.04 \mathrm{mg} /$ $\mathrm{kg}$ (for HPLC), 0.001 to $0.009 \mathrm{mg} / \mathrm{kg}$ (for GC), and 0.005 to $0.009 \mathrm{mg} / \mathrm{kg}$ (for $L C-M S / M S$ ). LODs for all pesticides analyzed were lower than the respective maximum residue levels (MRLs) established by the European regulation for fruits. Linearity was evaluated by the calculation of a fivepoint linear plot with three replicates, based on linear regression and correlation coefficient $\left(\mathrm{R}^{2}\right)$. All pesticides showed linearity in the concentration range 0.03-5.0 $\mathrm{mg} / \mathrm{kg}$ (for spectrophotometric), 0.02-2.0 $\mathrm{mg} / \mathrm{kg}$ (for HPLC), $0.003-5.0 \mathrm{mg} / \mathrm{kg}$ (for GC), and 0.002-1.00 mg/ $\mathrm{kg}$ (for LC-MS/MS) with correlation coefficients higher than 0.99553. Mean recoveries for fruit samples spiked at three fortification levels ranged from 71.07 to $119.90 \%$ with exceptions of bupirimate, dimethomorph (40-70\%) and triadimenol (121\%), with RSDs of $0.9-9.4 \%$ for a period of five days. However, the range of $60-140 \%$ can be used in routine multiresidue analysis [27-28]. These results indicated that the validation parameters were good, and consequently that fungicides were satisfactorily determined using these methods.

These results suggest that the sample preparation procedures and various methods of instrumental analysis are suitable for the analysis of the wide-ranging group of fungicide residues in fruit samples.

\section{Trends Over the Last 10 Years of Fungicide Residues in Fruits}

A total of 974 fruit samples were analyzed in 200514. Fungicide residues in $52.0 \%$ of the samples were detected. There were pesticide residues below the MRLs in $50.2 \%$ samples, while $1.7 \%$ of tested samples exceeded MRLs. Pesticide residues were not detected in $48.0 \%$ of samples. The percentage of contaminated samples by fungicides in 2005 was $53.0 \%$, in $200645.0 \%$, in 2007 $61.0 \%$, in $200865.7 \%$, in $200945.7 \%$, in $201035.2 \%$, in $201169.2 \%$, in $201233.3 \%$, in $201372.4 \%$, and in $201456.1 \%$ (Fig. 2). The percentage of samples in which exceedances of the maximum residue levels (MRLs) of 
Table 3. Validation results.

\begin{tabular}{|c|c|c|c|c|c|c|c|c|c|}
\hline \multirow[b]{2}{*}{ Pesticide } & \multicolumn{3}{|c|}{ Apple } & \multicolumn{3}{|c|}{ Black currant } & \multicolumn{3}{|c|}{ Sour cherry } \\
\hline & $\begin{array}{c}\text { Recovery (mean) } \\
(\%)\end{array}$ & $\begin{array}{l}\text { RSD } \\
(\%)\end{array}$ & $\begin{array}{c}U \\
(\%)\end{array}$ & $\begin{array}{l}\text { Recovery } \\
(\text { mean) }(\%)\end{array}$ & $\begin{array}{l}\text { RSD } \\
(\%)\end{array}$ & $\mathrm{U}(\%)$ & $\begin{array}{l}\text { Recovery } \\
(\text { mean) }(\%)\end{array}$ & $\begin{array}{l}\text { RSD } \\
(\%)\end{array}$ & $\begin{array}{l}\mathrm{U} \\
(\%)\end{array}$ \\
\hline Azaconazole & 93.8 & 7 & 17.2 & 86 & 7.0 & 19 & 101 & 7.8 & 16 \\
\hline Azoxystrobin & 98.8 & 6 & 16.3 & 88 & 6.1 & 18 & 98 & 6.9 & 16 \\
\hline Benalaxyl & 87.1 & 7 & 18.5 & 88 & 6.5 & 18 & 88 & 7.5 & 18 \\
\hline Bendiocarb & 98.0 & 6 & 16.4 & 97 & 6.5 & 17 & 95 & 7.2 & 17 \\
\hline Benfuracarb & 86.3 & 10 & 18.6 & 95 & 6.2 & 17 & 96 & 8.0 & 17 \\
\hline Bensulfuron-methyl & 96.6 & 7 & 16.7 & 85 & 7.6 & 19 & 97 & 7.2 & 17 \\
\hline Bitertanol & 83.0 & 9 & 19.4 & 75 & 6.6 & 22 & 83 & 9.4 & 19 \\
\hline Boscalid & 95.2 & 8 & 16.9 & 86 & 6.9 & 19 & 95 & 8.1 & 17 \\
\hline Bromuconazole & 85.7 & 7 & 18.8 & 84 & 7.3 & 19 & 85 & 8.2 & 19 \\
\hline Bupirimate & 75.9 & 7 & 21.2 & 85 & 6.6 & 19 & 74 & 8.8 & 22 \\
\hline Captafol & 99.6 & 7 & 16.2 & 73 & 6.7 & 22 & 101 & 7.8 & 16 \\
\hline Carbendazim & 83.5 & 15 & 19.3 & 95 & 8.9 & 17 & 85 & 7.7 & 19 \\
\hline Cyproconazole & 86.0 & 7 & 18.7 & 75 & 6.6 & 22 & 85 & 8.2 & 19 \\
\hline Cyprodinil & 95.2 & 8 & 16.9 & 78 & 6.6 & 21 & 86 & 7.3 & 19 \\
\hline Dichlofluanid & 83.1 & 8 & 19.4 & 83 & 10.6 & 19 & 82 & 11.2 & 20 \\
\hline Difenoconazole & 86.2 & 10 & 18.7 & 73 & 6.7 & 22 & 92 & 7.4 & 18 \\
\hline Dimethomorph & 75.9 & 7 & 21.2 & 85 & 6.6 & 19 & 74 & 8.8 & 22 \\
\hline Dimoxystrobin & 85.8 & 7 & 18.8 & 85 & 6.3 & 19 & 85 & 7.9 & 19 \\
\hline Diniconazole & 86.3 & 10 & 18.6 & 95 & 6.2 & 17 & 96 & 8.0 & 17 \\
\hline Etaconazole & 93.8 & 7 & 17.2 & 81 & 6.6 & 20 & 98 & 6.9 & 16 \\
\hline Famoxadon & 92.5 & 6 & 17.4 & 87 & 6.4 & 19 & 97 & 7.3 & 17 \\
\hline Fenarimol & 76.6 & 8 & 21.0 & 96 & 6.5 & 17 & 86 & 8.2 & 19 \\
\hline Fenbuconazole & 93.4 & 7 & 17.2 & 87 & 6.0 & 19 & 91 & 7.1 & 18 \\
\hline Fenhexamid & 76.0 & 8 & 21.2 & 77 & 7.4 & 24 & 75 & 8.7 & 22 \\
\hline Fenpropimorph & 75.5 & 6 & 21.3 & 82 & 6.1 & 20 & 77 & 8.5 & 21 \\
\hline Fludioxonil & 86.2 & 10 & 18.7 & 95 & 8.9 & 17 & 95 & 8.5 & 17 \\
\hline Fluopicolid & 77.3 & 7 & 20.8 & 86 & 6.8 & 19 & 83 & 9.4 & 19 \\
\hline Flusilazole & 86.0 & 7 & 18.7 & 75 & 7.0 & 22 & 74 & 8.8 & 22 \\
\hline Flutolanil & 95.2 & 8 & 16.9 & 94 & 6.9 & 17 & 95 & 8.5 & 17 \\
\hline Flutriafol & 86.2 & 10 & 18.7 & 86 & 6.9 & 19 & 86 & 7.3 & 19 \\
\hline Folpet & 84.9 & 8 & 19.0 & 92 & 5.7 & 17 & 94 & 7.6 & 17 \\
\hline Hexaconazole & 93.8 & 7 & 17.2 & 86 & 7.0 & 19 & 101 & 7.8 & 16 \\
\hline Imazalil & 76.6 & 8 & 21.0 & 96 & 6.5 & 17 & 86 & 8.2 & 19 \\
\hline Iprodione & 74.0 & 8 & 21.7 & 95 & 6.2 & 17 & 92 & 7.4 & 18 \\
\hline Iprovalicarb & 99.6 & 7 & 16.2 & 73 & 6.7 & 22 & 101 & 7.8 & 16 \\
\hline Isoprothiolane & 86.0 & 7 & 18.7 & 75 & 6.6 & 22 & 86 & 7.2 & 19 \\
\hline Kresoxim-methyl & 99.6 & 7 & 16.2 & 99 & 7.0 & 16 & 85 & 7.1 & 19 \\
\hline Mepanipyrim & 97.0 & 10 & 16.6 & 95 & 8.9 & 17 & 78 & 8.5 & 21 \\
\hline
\end{tabular}


Continued

\begin{tabular}{|c|c|c|c|c|c|c|c|c|c|}
\hline Metalaxyl & 98.8 & 6 & 16.3 & 88 & 6.1 & 18 & 98 & 6.9 & 16 \\
\hline Metconazole & 77.3 & 7 & 20.8 & 75 & 7.0 & 22 & 95 & 7.8 & 17 \\
\hline Metrafenone & 85.7 & 7 & 18.8 & 86 & 6.9 & 19 & 74 & 8.8 & 22 \\
\hline Myclobutanil & 92.5 & 6 & 17.4 & 87 & 6.4 & 19 & 97 & 7.3 & 17 \\
\hline Oxadixyl & 84.6 & 8 & 19.0 & 82 & 7.0 & 20 & 82 & 11.3 & 20 \\
\hline Paclobutrazol & 86.9 & 7 & 18.5 & 76 & 7.6 & 21 & 86 & 7.4 & 19 \\
\hline Penconazole & 93.4 & 7 & 17.2 & 87 & 6.0 & 19 & 91 & 7.1 & 18 \\
\hline Pencycuron & 84.5 & 7 & 19.1 & 83 & 6.9 & 19 & 84 & 7.2 & 19 \\
\hline Picoxystrobin & 100.6 & 7 & 16.0 & 85 & 6.9 & 19 & 104 & 7.2 & 15 \\
\hline Prochloraz & 98.0 & 6 & 16.4 & 88 & 6.7 & 18 & 97 & 7.2 & 17 \\
\hline Procymidone & 98.8 & 6 & 16.3 & 73 & 6.7 & 22 & 95 & 7.2 & 17 \\
\hline Propiconazole & 97.0 & 7 & 16.6 & 96 & 6.5 & 17 & 85 & 7.1 & 19 \\
\hline Prothioconazol-desthio & 86.0 & 7 & 18.7 & 75 & 7.0 & 22 & 74 & 8.8 & 22 \\
\hline Pyraclostrobin & 76.4 & 11 & 21.1 & 99 & 7.0 & 16 & 94 & 9.1 & 17 \\
\hline Pyrazofos & 87.4 & 7 & 18.4 & 84 & 7.3 & 19 & 85 & 7.9 & 19 \\
\hline Pyrimethanil & 95.0 & 7 & 16.9 & 96 & 7.0 & 17 & 95 & 7.8 & 17 \\
\hline Qinoxyfen & 76.1 & 8 & 21.1 & 88 & 6.7 & 18 & 88 & 7.5 & 18 \\
\hline Tebuconazol & 99.6 & 7 & 16.2 & 99 & 7.0 & 16 & 85 & 7.1 & 19 \\
\hline Tetraconazole & 86.3 & 10 & 18.6 & 95 & 6.2 & 17 & 96 & 8.0 & 17 \\
\hline Thiabendazol & 95.0 & 7 & 16.9 & 81 & 6.6 & 20 & 95 & 7.3 & 17 \\
\hline Tolclofos-methyl & 96.6 & 7 & 16.7 & 85 & 7.6 & 19 & 85 & 7.8 & 19 \\
\hline Tolylfluanid & 86.3 & 10 & 18.6 & 95 & 6.2 & 17 & 96 & 8.0 & 17 \\
\hline Triadimefon & 98.8 & 6 & 16.3 & 88 & 6.1 & 18 & 98 & 6.9 & 16 \\
\hline Triadimenol & 93.8 & 7 & 17.2 & 86 & 7.0 & 19 & 101 & 7.8 & 16 \\
\hline Trifloxystrobin & 83.5 & 15 & 19.3 & 94 & 6.9 & 17 & 95 & 9.9 & 17 \\
\hline Triticonazole & 83.1 & 8 & 19.4 & 83 & 10.6 & 19 & 82 & 11.2 & 20 \\
\hline Vinclozolin & 82.2 & 7 & 19.3 & 85 & 7.3 & 19 & 86 & 8.2 & 19 \\
\hline Zoxamide & 83.0 & 9 & 19.4 & 95 & 6.2 & 17 & 95 & 8.1 & 17 \\
\hline
\end{tabular}

U - uncertainty

fungicides were observed fell within the range of 0.8$2.6 \%$, excluding 2007 and 2013 , when it was $4.0 \%$ and $4.8 \%$, respectively. No MRL exceedances occurred in 2012 and 2014.

According to Poland's Central Statistical Office (GUS), in 2005-14 mostly herbicides (55\%) were used in chemical plant protection. The second important group of utilized preparations was fungicides (29.4\%) [29]. Fig. 2 shows the trend of fungicide consumption in 2005-14 in Poland. The trend of fungicide consumption was characterized by small decreases and increases and was not strongly correlated with the prevailing weather conditions. Weather conditions play a crucial role in the development of fungal pathogens. On the development of fungal diseases, among others, air humidity, precipitation, and temperature have an impact. At high humidity and moderate air temperature, fruit bodies with ascospores matue quickly. Precipitation contributes to germination of spores and propagation of infections. In our study, the weather could influence the obtained results. For example, 2007 and 2013 resulted in a high percentage of samples with residues characterized by high precipitation and temperatures.

\section{The Most Frequently Detected Fungicide Groups}

In the research period under discussion, anilinopyrimidines, phthalimides, carbamates, carboxamides, and triazoles were the most frequently detected fungicide 


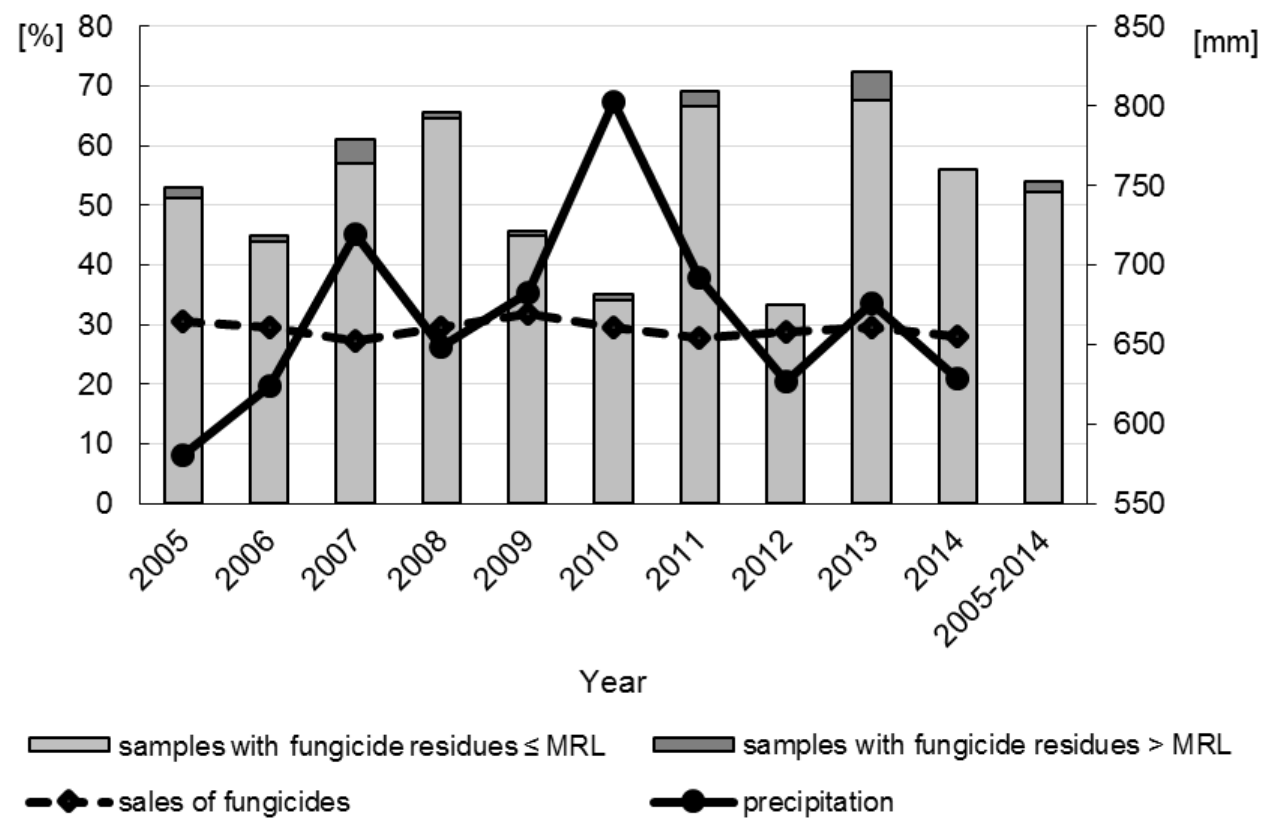

Fig. 2. Percentage of fruit samples contaminated by fungicides, sales of fungicides, and the average annual precipitation for Poland in 2005-14.

groups (Fig. 3, Table 1). The characteristics of the detected fungicide groups in this study are as follows.

Group 22, phthalimide fungicides: In 2005-07, as well as in 2009 , the most frequently detected were phthalimides. Phthalimide fungicides such as captafol, captain, and folpet are multi-site inhibitors that affect energy production. The main mode of action of these substances consists in blocking of respiratory processes of pathogens by creating persistent compounds in the structure of enzymatic proteins. Phthalimide fungicides, blocking many enzymes acting at various stages of respiration, hinder the energetic processes of a fungus. Captan and folpet are carcinogenic substances.
Group 7, carbamate fungicides: In 2008 and in 201014 the most frequently detected fungicides were those from the carbamate group. Carbamate fungicides disrupt the formation of fungal cell walls by interfering with synthesis of phospholipids and fatty acids. They also affect mycelial growth, spore production, and germination.

Group 8, carboxamide fungicides: Beginning in 2009, substances from the carboxamide group were detected in the analyzed samples. Carboxamide fungicides inhibit mitochondrial complex II of fungal respiration, interrupting electron transport in the mitochondrial respiratory chain.

Group 30, triazole fungicides: Triazole fungicides were detected systematically at a similar level (below 10

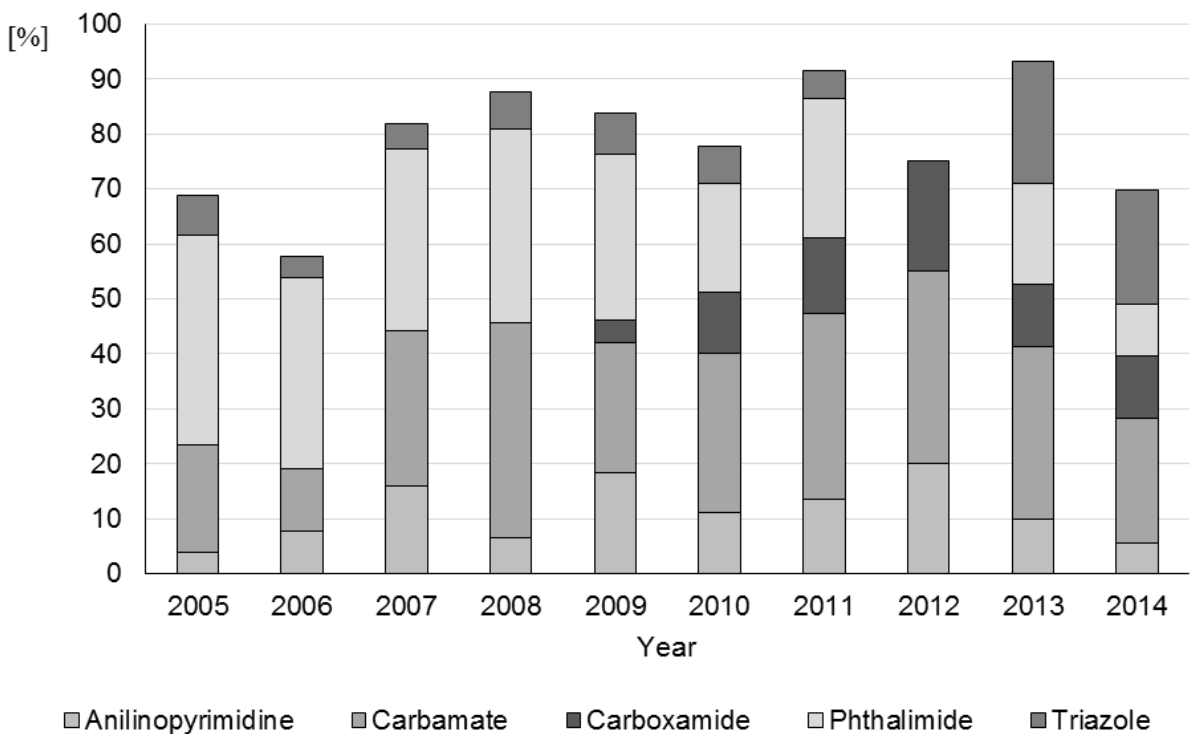

Fig. 3. The most frequently detected fungicide groups in 2005-14. 
Table 4. Summary of fungicide residues detected in fruit samples in 2005-14.

\begin{tabular}{|c|c|c|c|c|c|c|}
\hline Substance group & Active substance & Chemical structure & \begin{tabular}{|c|} 
No. of \\
samples \\
with residues \\
$(\%)$ \\
\end{tabular} & $\begin{array}{c}\text { No. of } \\
\text { samples } \\
>\text { MRL }(\%)\end{array}$ & $\begin{array}{c}\text { Range of } \\
\text { concentration } \\
(\mathrm{mg} / \mathrm{kg})\end{array}$ & $\begin{array}{c}\text { Positive fruits } \\
\text { (No. of detected, MRL) }\end{array}$ \\
\hline \multirow[t]{2}{*}{$\begin{array}{l}\text { Anilinopyrimidine } \\
\text { (Group 3) }\end{array}$} & Cyprodinil & & $\begin{array}{c}38 \\
(3.9)\end{array}$ & $\begin{array}{c}2 \\
(0.2)\end{array}$ & $0.01-0.28$ & $\begin{array}{c}\text { Blueberry }(1, M R L=5), \\
\text { sweet cherry }(1, M R L=1), \\
\text { apple }(10, M R L=0.05-1), \\
\text { currant }(2, M R L=5), \\
\text { strawberry }(23, M R L=3-5), \\
\text { grape }(1, M R L=5)\end{array}$ \\
\hline & Pyrimethanil & & $\begin{array}{c}42 \\
(4.3)\end{array}$ & $\begin{array}{c}3 \\
(0.3)\end{array}$ & $0.01-2.40$ & $\begin{array}{l}\text { Apple }(33, M R L=0.01-5), \\
\text { raspberry }(5, M R L=10), \\
\text { strawberry }(4, M R L=2-5)\end{array}$ \\
\hline $\begin{array}{l}\text { Benzimidazole } \\
\text { (Group 5) }\end{array}$ & Carbendazim & & $\begin{array}{c}3 \\
(0.3)\end{array}$ & $\begin{array}{c}0 \\
(0)\end{array}$ & 0.04-0.07 & Apple (3, MRL $=0.2)$ \\
\hline $\begin{array}{l}\text { Carbamate } \\
\text { (Group 7) }\end{array}$ & $\begin{array}{l}\text { Dithiocarbamates } \\
\text { - DTC }\end{array}$ & - & $212(21.8)$ & $\begin{array}{c}0 \\
(0)\end{array}$ & $0.05-2.74$ & $\begin{array}{c}\text { Gooseberry }(2, M R L=5), \\
\text { pear }(14, M R L=5), \text { apple } \\
(87, M R L=3-5), \text { currant } \\
(62, M R L=5) \text {, plum } \\
(2, M R L=2), \text { strawberry } \\
(24, M R L=2-10), \text { sour } \\
\text { cherry }(21, M R L=1-2)\end{array}$ \\
\hline $\begin{array}{l}\text { Carboxamide } \\
\text { (Group 8) }\end{array}$ & Boscalid & & $\begin{array}{c}42 \\
(4.3)\end{array}$ & $\begin{array}{c}0 \\
(0)\end{array}$ & $0.01-3.31$ & $\begin{array}{c}\text { Gooseberry }(1, M R L=10), \\
\text { blueberry }(1, M R L=10), \\
\text { sweet cherry }(1, M R L=3), \\
\text { pear }(4, M R L=2) \text {, apple } \\
(13, M R L=2) \text {, currant } \\
(8, M R L=10), \text { strawberry } \\
(13, M R L=10) \text {, sour cherry } \\
(1, M R L=4)\end{array}$ \\
\hline \multirow{2}{*}{$\begin{array}{l}\text { Dicarboximide } \\
\text { (Group 13) }\end{array}$} & Iprodione & & $\begin{array}{c}14 \\
(1.4)\end{array}$ & $\begin{array}{c}0 \\
(0)\end{array}$ & $0.01-0.62$ & $\begin{array}{c}\text { Raspberry }(2, M R L=10), \\
\text { strawberry }(12, M R L=10- \\
15)\end{array}$ \\
\hline & Procymidone & & $\begin{array}{c}12 \\
(1.2)\end{array}$ & $\begin{array}{c}3 \\
(0.3)\end{array}$ & $0.02-0.84$ & $\begin{array}{c}\text { Raspberry }(3, \mathrm{MRL}=10), \\
\text { currant }(2, \mathrm{MRL}=0.02), \\
\text { strawberry }(7, \mathrm{MRL}=0.2-5)\end{array}$ \\
\hline $\begin{array}{l}\text { Hydroxyanilide } \\
\text { (Group 14) }\end{array}$ & Fenhexamid & & $\begin{array}{c}16 \\
(1.6)\end{array}$ & $\begin{array}{c}0 \\
(0)\end{array}$ & $0.03-0.71$ & $\begin{array}{l}\text { Sweet cherry }(1, \mathrm{MRL}=5), \\
\text { raspberry }(5, \mathrm{MRL}=10), \\
\text { strawberry }(10, \mathrm{MRL}=5)\end{array}$ \\
\hline $\begin{array}{l}\text { Pyrimidine } \\
\text { (Group 21) }\end{array}$ & Fenarimol & & $\begin{array}{l}16 \\
(1.6)\end{array}$ & $\begin{array}{c}0 \\
(0)\end{array}$ & $0.01-0.08$ & $\begin{array}{c}\text { Currant }(1, M R L=1), \\
\text { sour cherry }(15, M R L=1)\end{array}$ \\
\hline \multirow{2}{*}{$\begin{array}{l}\text { Phthalimide } \\
\text { (Group 22) }\end{array}$} & Captan & & $204(20.9)$ & $\begin{array}{c}0 \\
(0)\end{array}$ & $0.01-2.83$ & $\begin{array}{l}\text { Peach }(2, M R L=3) \text {, sweet } \\
\text { cherry }(2, M R L=5) \text {, pear } \\
(11, M R L=4) \text {, apple }(105, \\
\text { MRL=3), sour cherry }(84, \\
\text { MRL }=2-5)\end{array}$ \\
\hline & Folpet & & $\begin{array}{c}11 \\
(1.1)\end{array}$ & $\begin{array}{c}0 \\
(0)\end{array}$ & $0.02-2.70$ & $\begin{array}{l}\text { Apple }(4, \mathrm{MRL}=3) \text {, straw- } \\
\text { berry }(7, \mathrm{MRL}=3)\end{array}$ \\
\hline
\end{tabular}


Continued

\begin{tabular}{|c|c|c|c|c|c|c|}
\hline $\begin{array}{l}\text { Phenylpyrrole } \\
\text { (Group 24) }\end{array}$ & Fludioxonil & & $\begin{array}{c}22 \\
(2.3)\end{array}$ & $\begin{array}{c}0 \\
(0)\end{array}$ & $0.01-0.30$ & $\begin{array}{c}\text { Sweet cherry }(1, \mathrm{MTL}=5), \\
\text { pear }(1, \mathrm{MRL}=5) \text {, apple }(1, \\
\mathrm{MRL}=5), \text { currant } \\
(1, \mathrm{MRL}=3), \text { strawberry } \\
(17, \mathrm{MRL}=3), \text { grape } \\
(1, \mathrm{MRL}=5)\end{array}$ \\
\hline $\begin{array}{l}\text { Pyrimidinol } \\
\text { (Group 26) }\end{array}$ & Bupirimate & & $\begin{array}{c}6 \\
(0.6)\end{array}$ & $\begin{array}{c}0 \\
(0)\end{array}$ & $0.02-0.82$ & $\begin{array}{l}\text { Gooseberry }(2, M R L=5), \\
\text { currant }(4, M R L=0.5-5)\end{array}$ \\
\hline $\begin{array}{l}\text { Sulphamide } \\
\text { (Group 28) }\end{array}$ & Tolylfluanid & & $\begin{array}{c}34 \\
(3.5)\end{array}$ & $\begin{array}{c}1 \\
(0.1)\end{array}$ & $0.02-1.80$ & $\begin{array}{c}\text { Pear }(1, M R L=5) \text {, apple } \\
(19, M R L=5), \text { raspberry } \\
(4, M R L=5) \text {, currant } \\
(1, M R L=0.02), \text { strawberry } \\
(9, M R L=2-5)\end{array}$ \\
\hline \multirow{3}{*}{$\begin{array}{l}\text { Strobilurin } \\
\text { (Group 29) }\end{array}$} & Azoxystrobin & & $\begin{array}{c}1 \\
(0.1)\end{array}$ & $\begin{array}{c}0 \\
(0)\end{array}$ & 0.06 & Currant $(1, \mathrm{MRL}=5)$ \\
\hline & Pyraclostrobin & & $\begin{array}{c}5 \\
(0.5)\end{array}$ & $\begin{array}{c}1 \\
(0.1)\end{array}$ & $0.04-0.61$ & $\begin{array}{c}\text { Gooseberry }(1, \mathrm{MRL}=3) \text {, } \\
\text { pear }(1, \mathrm{MRL}=0.5) \text {, currant } \\
(3, \mathrm{MRL}=3)\end{array}$ \\
\hline & Trifloxystrobin & & $\begin{array}{c}22 \\
(2.7)\end{array}$ & $\begin{array}{c}0 \\
(0)\end{array}$ & $0.01-0.16$ & $\begin{array}{c}\text { Gooseberry }(1, M R L=1), \\
\text { sweet cherry }(1, M R L=1) \text {, } \\
\text { pear }(2, M R L=0.5) \text {, apple } \\
(11, M R L=0.5) \text {, currant } \\
(7, M R L=0.2-1)\end{array}$ \\
\hline \multirow{6}{*}{$\begin{array}{l}\text { Triazole } \\
\text { (Group 30) }\end{array}$} & Bitertanol & & $\begin{array}{c}2 \\
(0.2)\end{array}$ & $\begin{array}{c}0 \\
(0)\end{array}$ & 0.10 & Sour cherry $(2, M R L=1)$ \\
\hline & Cyproconazole & & $\begin{array}{c}1 \\
(0.1)\end{array}$ & $\begin{array}{c}1 \\
(0.1)\end{array}$ & 0.09 & Gooseberry $(1, \mathrm{MRL}=0.05)$ \\
\hline & Difenoconazole & & $\begin{array}{c}27 \\
(2.8)\end{array}$ & $\begin{array}{c}2 \\
(0.2)\end{array}$ & $0.02-0.43$ & $\begin{array}{c}\text { Gooseberry }(2, \mathrm{MRL}=0.1), \\
\text { currant }(24, \mathrm{MRL}=0.2), \\
\text { sour cherry }(1, \mathrm{MRL}=0.3)\end{array}$ \\
\hline & Flusilazole & & $\begin{array}{c}33 \\
(3.4)\end{array}$ & $\begin{array}{c}6 \\
(0.6)\end{array}$ & $0.01-0.29$ & $\begin{array}{c}\text { Pear }(1, \text { MRL }=0.02) \text {, apple } \\
(7, \text { MRL }=0.02-0.2) \text {, currant } \\
(16, \text { MRL }=0.02-0.2) \text {, sour } \\
\text { cherry }(9, \text { MRL }=0.2)\end{array}$ \\
\hline & Propiconazole & & $\begin{array}{c}1 \\
(0.1)\end{array}$ & $\begin{array}{c}1 \\
(0.1)\end{array}$ & 0.14 & Gooseberry $(1, \mathrm{MRL}=0.05)$ \\
\hline & Tebuconazole & & $\begin{array}{c}11 \\
(1.1)\end{array}$ & $\begin{array}{c}0 \\
(0)\end{array}$ & $0.02-0.21$ & $\begin{array}{l}\text { Apple }(4, \mathrm{MRL}=1), \text { plum } \\
(6, \mathrm{MRL}=0.5-1), \text { sour } \\
\text { cherry }(1, \mathrm{MRL}=5)\end{array}$ \\
\hline
\end{tabular}


\%) until 2011. In 2012, triazole residues were not detected. On the other hand, detection of substances from this group has increased over the last two years. Triazole fungicides are recognized as carcinogens and mutagens that can weaken the immune system (cancer-causing, reproductive disorders, endocrine disorders, and neurotoxic).

Group 3, anilinopyrimidine fungicides: In 2005-14, anilinopyrimidines were detected. The anilinopyrimidine fungicides registered on fruits include cyprodinil, pyrimethanil, and mepanipyrim. The main mode of action of these substances consists in blocking the synthesis of amino acids. This inhibits fungal growth both inside and outside the leaf.

\section{The Most Frequently Detected Active Substances}

The most commonly detected pesticides were: dithiocarbamates (212 samples), captan (204 samples), pyrimethanil and boscalid (42 samples), cyprodinil (38 samples), tolylfluanid (34 samples), flusilazole (33 samples), difenoconazole (27 samples), trifloxystrobin and fludioxonil (22 samples), fenhexamid and fenarimol (16 samples), iprodione (14 samples), procymidone (12 samples), tebuconazole and folpet (11 samples), bupirimate (six samples), pyraclostrobin (five samples), and carbendazim (three samples). Bitertanol in two samples and cyproconazole, propiconazole, and azoxystrobin only in one sample each were detected (Table 4).

Ditihocarbamates (carbamate, group 7) belonging to the most widespread active substances in the world, occurred the most frequently in apple and currant samples in this investigation. Overall, DTC fungicides found in this study were similar to those found in other studies from other countries (apples, pears, grapes) [30]. The level of DTC in samples ranged from 0.05 to $2.74 \mathrm{mg} / \mathrm{kg}$. The levels were lower than the level of dithiocarbamates found in fruit and vegetable samples from southeastern Poland (3.24 mg/kg) [31]. Although dithiocarbamates were present in 212 samples ( $21.7 \%$ of all tested samples), any sample with levels above the MRL was noted.

Captan belonging to the phthalimide class (group 22), was identified in 204 samples of peaches, apples, pears, and sweet and sour cherries. Boscalid belonging to the class of carboxamide (group 8), was identified in 42 samples of strawberries, currants, gooseberries, apples, blueberries, pears, and sweet and sour cherries. The highest concentrations were noted for boscalid and captan, ranging from $2.83 \mathrm{mg} / \mathrm{kg}$ (for cherry samples) to $3.31 \mathrm{mg} / \mathrm{kg}$ (for currant samples). The highest concentration for boscalid was observed in grapes from Turkey $(1.68 \mathrm{mg} / \mathrm{kg}$ ) [32].

Some pesticide concentrations exceeded their MRLs, such as flusilazole (seven samples), pyrimethanil (three samples), procymidone (three samples), cyprodinil (two samples), difenoconazole (two samples), and cyproconazole, propiconazole, tolylfluanid (in one sample each). More details are presented in Table 4.

Results showed the detection of different triazole fungicides in fruit samples. Difenoconazole and flusilazole indicated the highest concentration of $0.43 \mathrm{mg} / \mathrm{kg}$ and $0.29 \mathrm{mg} / \mathrm{kg}$ in currant, tebuconazole with a concentration of $0.29 \mathrm{mg} / \mathrm{kg}$ in plum, bitertanol with a concentration of $0.10 \mathrm{mg} / \mathrm{kg}$ in sour cherry, propiconazole and cyproconazole with a concentration of $0.14 \mathrm{mg} / \mathrm{kg}$ and $0.09 \mathrm{mg} / \mathrm{kg}$ in gooseberry. Flusilazole is broad-spectrum fungicide used to control fungal diseases in cereals, fruits, vegetables, and nuts [25]. The level of flusilazole in samples ranged from 0.01 to $0.29 \mathrm{mg} / \mathrm{kg}$, with six samples having levels above the MRL $(0.20 \mathrm{mg} / \mathrm{kg})$. This fungicide is moderately toxic to humans (class II) [33]. On the other hand, difenoconazole was identified in 27 samples of currants, gooseberries, and sour cherries. The level of difenoconazole in samples ranged from 0.02 to $0.43 \mathrm{mg} / \mathrm{kg}$, with two samples having levels above the MRL $(0.30 \mathrm{mg} / \mathrm{kg})$. The World Health Organization [33] has classified difenocnazole as moderately toxic to humans (class II). The reported difenoconazole level was higher than its level in samples from Turkey (0.01-0.03 $\mathrm{mg} / \mathrm{kg}$ ) [32]. Accordingly, monitoring flusilazole and difenoconazole levels in fruits is important for human health.

During 10 years of testing, only $1.7 \%$ of fruit samples had residues exceeding MRL. In Brazil, 3\% among the 160 vegetable samples analyzed in 2001-10 had residues exceeding MRL [34]. Zicarii et al. [35] reported that 3.2\% among the 6,947 samples from Italy had residues above MRL. In turn, $8.4 \%$ of the 724 fruit and vegetable samples imported from South America to Denmark, Estonia, Finland, Norway, and Sweden had residues above the MRL [36].

\section{Occurrence of Fungicide Residues in a Particular Group of Fruits}

Berries and small fruits were the type of fruit where the residues of fungicides were the most frequently detected. Moreover, in the case of this type of fruit, among 320 analyzed samples, 12 (3.8\%) showed values above MRLs. The most frequently identified was dithiocarbamates in currants. Results obtained by other authors [37-38] show that berries (e.g., currants) more frequently contain pesticide residues than other fruits. In turn, the most frequently detected fungicide in pome fruits and stone fruits was captain, which was found in cherry and apple samples.

The percentage of contaminated samples was high (above 50\%) for three different fruits: currants (68.5\%), apples $(63.3 \%)$, and sour cherries $(54.6 \%)$. Percentages of contaminated samples below $48 \%$ had strawberries $(47.4 \%)$ and pears $(47.7 \%)$. Currants and apples had fungicides detected in nine consecutive years, with the exception of the years 2011 and 2012.

\section{Single and Multiple Fungicide Residues Detected in Samples}

Of the 935 samples, $32.1 \%$ contained only one substance and $22 \%$ contained between two and five substances. The multi-residue samples are shown in Fig. 4. 


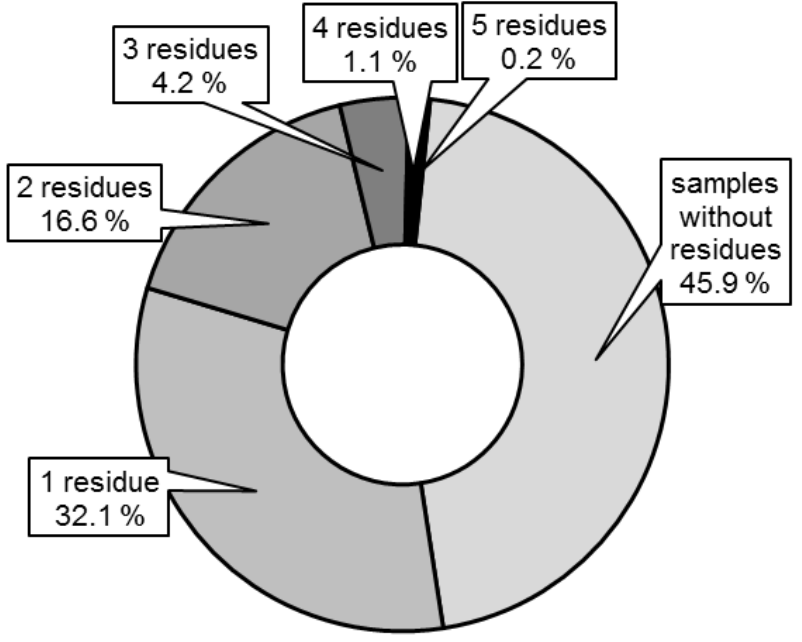

Fig. 4. Frequency of occurrence of samples without residues, with one residue, and with multi-residue in fruits.

Gooseberries had the highest number of samples with multiple residues ( $80.0 \%$ of positive gooseberry samples), followed by strawberries $(50.0 \%)$, apples $(45.9 \%)$, and currants $(41.4 \%)$, which was in accordance with a study conducted by Sadło et al. [39-40]. Dithiocarbamates and captan were the substances most often found in the multiresidue samples.

\section{Risk Assessment}

Humans are acute and chronically exposed to pesticide residues in food. These compounds can be harmful to humans even at very small concentrations. In the case of safety evaluations of pesticide residue for food intake, ARfD and ADI are the standards for risk assessment and they are basing on the acute and chronic toxicity of pesticides for humans. Exposure estimation was conducted on the results of monitoring fungicide residue detected in fruit samples in order to determine the shortand long-term risks. Table 5a shows the results of the evaluation of the acute health risks of exposure of children and adults. Table $5 \mathrm{~b}$ shows the long-term risk calculated additionally for Polish consumers and WHO cluster diet E (Austria, Belgium, Croatia, Czech Republic, Denmark, France, Germany, Hungary, Ireland, Luxemburg, Malta, Netherlands, Slovakia, Slovenia, Switzerland, United Kingdom, Northern Ireland, and Poland) related to fruit consumption containing fungicide residues. If the results of such analytes exceed $100 \%$, there is a potential risk to consumers.

\section{Short-Term Risk}

In the case of residues exceeding MRL, informative notifications were sent under the Rapid Alert System for Food and Feed (RASFF). Short-term exposure was calculated for pesticides exceeding MRLs and is shown in Table 5a. In the case of fruit consumption from northeastern Poland, short-term exposure didn't exceed $25 \%$ for the group of toddlers and $5 \%$ for the adults. The highest values of short-term exposure for the children were connected with the presence of cyprodinil in apples $(21.6 \%$ ARfD) and procymidone in currants (17.1\% ARfD), and was $4.5 \%$ and $7.5 \%$ ARfD for the adults, respectively. The results for the short-term risk assessments should be considered good.

\section{Long-Term Risk}

The percent ratios of EDI to ADI of 23 pesticides were very low $-0.01 \%$ for azoxystrobine, fenhexamide, fenarimol, and fludioxonil (adults), and up to 30.27\%

Table 5. Risk assessment in 2005-14.

a) Estimation of short-term (acute) dietary consumer exposure to pesticide residues.

\begin{tabular}{|c|c|c|c|c|c|c|c|c|c|c|}
\hline \multirow[b]{2}{*}{ Fruit } & \multirow[b]{2}{*}{$\begin{array}{c}\text { Active } \\
\text { substance }\end{array}$} & \multirow[b]{2}{*}{$\begin{array}{c}\mathrm{HR} \\
(\mathrm{mg} / \mathrm{kg})\end{array}$} & \multirow[b]{2}{*}{ MRL } & \multirow[b]{2}{*}{$\begin{array}{c}\text { Times } \\
\text { exceeded } \\
\text { MRL }\end{array}$} & \multirow[b]{2}{*}{$\begin{array}{c}\mathrm{ARfD}^{*} \\
(\mathrm{mg} / \mathrm{kg} \\
\mathrm{bw})\end{array}$} & \multicolumn{2}{|c|}{ Adults } & \multicolumn{2}{|c|}{ Children } & \multirow[b]{2}{*}{$\begin{array}{l}\text { Health } \\
\text { risk }\end{array}$} \\
\hline & & & & & & $\begin{array}{c}\text { Intake } \\
(\mathrm{mg} / \mathrm{kg} \mathrm{bw}) \\
\mathrm{x} 10^{-4}\end{array}$ & $\begin{array}{c}\% \\
\text { ARfD }\end{array}$ & $\begin{array}{c}\text { Intake } \\
(\mathrm{mg} / \mathrm{kg} \mathrm{bw}) \\
\mathrm{x} 10^{-4}\end{array}$ & $\begin{array}{c}\% \\
\text { ARfD }\end{array}$ & \\
\hline \multirow{2}{*}{ Apple } & Cyprodinil & 0.09 & 0.05 & 1.8 & 0.03 & 13.5 & 4.5 & 64.8 & 21.6 & No \\
\hline & Pyrimethanil & 0.20 & 0.01 & 20 & Not appl. & - & - & - & - & - \\
\hline \multirow{3}{*}{ Currant } & Difenoconazole & 0.43 & 0.05 & 8.6 & 0.16 & 6.8 & 0.4 & 15.5 & 1.0 & No \\
\hline & Flusilazole & 0.29 & 0.02 & 14.5 & 0.005 & 4.6 & 0.9 & 10.4 & 2.1 & No \\
\hline & Procymidone & 0.57 & 0.02 & 28.5 & 0.012 & 9.0 & 7.5 & 20.5 & 17.1 & No \\
\hline \multirow{2}{*}{ Gooseberry } & Cyproconazole & 0.09 & 0.05 & 1.8 & 0.02 & 0.9 & 0.4 & 1.9 & 0.9 & No \\
\hline & Propiconazole & 0.14 & 0.05 & 2.8 & 0.03 & 1.4 & 0.5 & 3.0 & 1.0 & No \\
\hline Strawberry & Tolylfluanid & 0.49 & 0.02 & 24.5 & 0.25 & 12.9 & 0.5 & 24.0 & 1.0 & No \\
\hline
\end{tabular}

HR - Highest residue, MRL - Maximum Residue Limits, ARfD - Acute Reference Dose, bw - body weight.

* ARfD values are derived from the pesticide database (EU Pesticides database) [41]. 
b) Risk estimates based on comparison of consumed groups of pesticides in the mean concentration with acceptable daily intake.

\begin{tabular}{|c|c|c|c|c|c|c|c|c|c|}
\hline \multirow[b]{2}{*}{ Substance group } & \multirow[b]{2}{*}{$\begin{array}{l}\text { Active sub- } \\
\text { stance }\end{array}$} & \multirow[b]{2}{*}{$\begin{array}{c}\text { ADI } \\
(\mathrm{mg} / \mathrm{kg} \\
\left.\text { b.w. } \mathrm{d}^{-1}\right)\end{array}$} & \multirow{2}{*}{$\begin{array}{c}\text { EDI } \\
(\mathrm{g} / \mathrm{kg} \text { b.w. } \\
\left.\mathrm{d}^{-1}\right) \\
\times 10^{-3}\end{array}$} & \multicolumn{6}{|c|}{ HQ [\%] } \\
\hline & & & & $\begin{array}{l}\text { Polish } \\
\text { general }\end{array}$ & $\begin{array}{c}\text { UK } \\
\text { adults } \\
\text { (mean) }\end{array}$ & $\begin{array}{c}\text { UK adults } \\
(97.5 \\
\text { percentile })\end{array}$ & $\begin{array}{l}\text { UK } \\
\text { toddler } \\
\text { (mean) }\end{array}$ & $\begin{array}{l}\text { UK toddler } \\
\quad(97.5 \\
\text { percentile })\end{array}$ & $\begin{array}{c}\text { WHO } \\
\text { cluster } \\
\text { E }\end{array}$ \\
\hline \multirow{2}{*}{$\begin{array}{l}\text { Anilinopyrimidine } \\
\text { (Group 3) }\end{array}$} & cyprodinil & 0.03 & 7.631 & 0.16 & 0.07 & 0.96 & 0.16 & 2.48 & 0.15 \\
\hline & pyrimathanil & 0.17 & 12.037 & 0.05 & 0.02 & 0.27 & 0.05 & 0.69 & 0.04 \\
\hline $\begin{array}{l}\text { Benzimidazole } \\
\text { (Group 5) }\end{array}$ & carbendazim & 0.02 & 5.155 & 0.16 & 0.08 & 0.97 & 0.16 & 2.52 & 0.15 \\
\hline $\begin{array}{c}\text { Carbamate } \\
\text { (Group 7) }\end{array}$ & $\begin{array}{l}\text { dithiocarba- } \\
\text { mate }\end{array}$ & 0.05 & 90.717 & 0.26 & 0.53 & 6.83 & 1.16 & 17.72 & 1.05 \\
\hline $\begin{array}{l}\text { Carboxamide } \\
\text { (Group 8) }\end{array}$ & boscalid & 0.04 & 16.551 & 0.13 & 0.12 & 1.56 & 0.26 & 4.04 & 0.24 \\
\hline \multirow{2}{*}{$\begin{array}{l}\text { Dicarboximide } \\
\text { (Group 13) }\end{array}$} & iprodione & 0.06 & 12.513 & 1.97 & 0.06 & 0.78 & 0.13 & 2.04 & 0.12 \\
\hline & procymidone & 0.0028 & 8.676 & 1.16 & 0.91 & 11.66 & 1.98 & 30.27 & 1.79 \\
\hline $\begin{array}{l}\text { Hydroxyanilide } \\
\text { (Group 14) }\end{array}$ & fenhexamid & 0.2 & 8.508 & 0.03 & 0.01 & 0.16 & 0.03 & 0.42 & 0.02 \\
\hline $\begin{array}{l}\text { Pyrimidine } \\
\text { (Group 21) }\end{array}$ & fenarimol & 0.01 & 5.481 & 0.01 & 0.16 & 2.06 & 0.35 & 5.35 & 0.32 \\
\hline \multirow{2}{*}{$\begin{array}{l}\text { Phthalimide } \\
\text { (Group 22) }\end{array}$} & captan & 0.1 & 53.555 & 0.34 & 0.16 & 2.02 & 0.34 & 5.23 & 0.31 \\
\hline & folpet & 0.1 & 13.595 & 0.09 & 0.04 & 0.51 & 0.09 & 1.33 & 0.08 \\
\hline $\begin{array}{l}\text { Phenylpyrrole } \\
\text { (Group 24) }\end{array}$ & fludioxonil & 0.37 & 6.679 & 0.35 & 0.01 & 0.07 & 0.01 & 0.18 & 0.01 \\
\hline $\begin{array}{l}\text { Pyrimidinol } \\
\text { (Group 26) }\end{array}$ & bupirymate & 0.05 & 5.995 & 0.08 & 0.04 & 0.45 & 0.08 & 1.17 & 0.07 \\
\hline $\begin{array}{l}\text { Sulphamide } \\
\text { (Group 28) }\end{array}$ & tolylfluanide & 0.1 & 11.160 & 0.02 & 0.03 & 0.42 & 0.07 & 1.09 & 0.06 \\
\hline \multirow{3}{*}{$\begin{array}{l}\text { Strobilurin } \\
\text { (Group 29) }\end{array}$} & azoxystrobin & 0.2 & 5.059 & 0.13 & 0.01 & 0.10 & 0.02 & 0.25 & 0.01 \\
\hline & pyraclostrobin & 0.03 & 6.171 & 0.04 & 0.06 & 0.77 & 0.13 & 2.01 & 0.12 \\
\hline & trifloxystrobin & 0.1 & 5.674 & 0.07 & 0.02 & 0.21 & 0.04 & 0.55 & 0.03 \\
\hline \multirow{6}{*}{$\begin{array}{c}\text { Triazole } \\
\text { (Group 30) }\end{array}$} & cyproconazole & 0.02 & 5.091 & 0.16 & 0.07 & 0.96 & 0.16 & 2.49 & 0.15 \\
\hline & difenoconazole & 0.01 & 7.134 & 0.45 & 0.21 & 2.68 & 0.46 & 6.97 & 0.41 \\
\hline & flusilazole & 0.002 & 6.406 & 2.04 & 0.94 & 12.05 & 2.05 & 31.29 & 1.85 \\
\hline & propiconazole & 0.04 & 5.144 & 0.08 & 0.04 & 0.48 & 0.08 & 1.26 & 0.07 \\
\hline & tebuconazole & 0.03 & 5.904 & 0.13 & 0.06 & 0.74 & 0.13 & 1.92 & 0.11 \\
\hline & bitertanol & 0.003 & 5.203 & 1.10 & 0.51 & 6.53 & 1.11 & 16.94 & 1.00 \\
\hline
\end{tabular}

for procymidone and $31.29 \%$ for flusilazole for toddlers, calculated on the 97.5 percentile.

\section{Conclusions}

The sample preparation techniques such as MSPD and QuEChERS combined with spectrophotometric and chromatographic (GC/ECD/NPD, HPLC/DAD/FLD, and LC/ $\mathrm{MS} / \mathrm{MS}$ ) methods were found to be suitable for the control of 77 fungicides in several fruits at concentrations lower than their established MRLs. The quantification with calibration curves made with spiked blank matrices was performed to completely remove any matrix effect. The methods were applied for 974 of fruit samples collected in Poland in the last 10 years (2005-14). Fungicide residues were found in $52.0 \%$ of the samples, with $50.2 \%$ samples containing pesticide residues below the maximum residue levels (MRLs), and $1.7 \%$ of tested samples exceeding MRLs. The percentage of contaminated samples was high (above 50\%) for three different fruits: currants (68.5\%), apples $(63.3 \%)$, and sour cherries $(54.6 \%)$. The present study shows that although fruits from northeastern Poland contained many fungicide residues, their consumption did not pose a danger to adult and child health.

The diversity of uses and the wide availability of fungicides causes their residues to reach the environment in an uncontrolled manner, and the human population is exposed to these substances. Therefore, monitoring pesticides in fruits is necessary in order to assess potential health risks and to improve the maximum residue limits (MRLs) for safe human consumption. 


\section{Acknowledgements}

This work was supported by the Ministry of Agriculture and Rural Development (Ministerstwo Rolnictwa i Rozwoju Wsi) under the Long-Term Programme of IPPNRI for 2011-15 "Protection of Cultivated Plants While Taking into Consideration Food Safety, Reduction of Yield Losses and the Threat to Humans, Farm Animals and the Environment" (contract No. HORkor.0660/IOR 2011-2015/2/2013), task No. 1.8. "Research on Pesticide Residues in Crops", and by the Ministry of Science. The authors are very grateful to Ms. Teresa Janowicz and Mrs. Patrycja Mojsak for assistance in conducting the research.

\section{References}

1. CHEN C., QIAN Y., CHEN Q., TAO C., LI C., LI Y. Evaluation of pesticide residues in fruits and vegetables from Xiamen, China. Food Control, 22, 1114, 2011.

2. FÜGEL R., CARLE R., SCHIEBER A. Quality and authenticity control of fruit pure'es, fruit preparations and jams - a review. Trends Food Sci. Tech., 16, 433, 2005.

3. ARR. Fruit market in Poland. http://www.arr.gov.pl. Accessed 26 Sep 2015, 2014.

4. CASTORIA R., LOGRIECO A. Mycotoxins in fruits and major fruit-derived products - an overview. In: Ward, O.P., \& Ray, R.C. (Eds.). Microbial Biotechnology in Horticulture, 2, 305, 2007.

5. FULLER K.B., ALSTON J.M., SAMBUCCI O. The value of powdery mildew resistance in grapes: Evidence from California. Wine Economics and Policy, 3, 90, 2014.

6. CARISSE O., BACON R., LEFEBVRE A. Grape powdery mildew (Erysiphe necator) risk assessment based on airborne conidium concentration. Crop Prot., 28, 1036, 2009.

7. MASIH E.I., SLEZACK-DESCHAUMES S., MARMARAS I., AIT BARKA E., VERNET G., CHARPENTIER C., ADHOLEYA A., PAUL B. Characterisation of the yeast Pichia membranifaciens and its possible use in the biological control of Botrytis cinerea, causing the grey mould disease of grapevines. FEMS Microbiol. Lett., 202, 227, 2001.

8. LI R., ZHANG H., LIU W., ZHENG X. Biocontrol of postharvest gray and blue mold decay of apples with Rhodotorula mucilaginosa and possible mechanisms of action. Int. J. Food Microbiol., 146, 151, 2011.

9. ZHIWEI W., TAO C., PEIPEI Q., XUEPIN Z., HAO X., XIANGYUN W., ZHANG H., WANG X. Dissipation of four fungicides on greenhouse strawberries and an assessment of their risks. Food Control, 55, 215, 2015.

10. KARABULUT O.A., COHEN L., WIESS B., DAUS A., LURIE S., DROBY S. Control of brown rot and blue mold of peach and nectarine by short hot water brushing and yeast antagonists. Postharvest Biol. Tec., 24, 103, 2002.

11. PERCIVAL G.C., NOVISS K., HAYNES I. Field evaluation of systemic inducing resistance chemicals at different growth stages for the control of apple (Venturia inaequalis) and pear (Venturia pirina) scab. Crop Prot., 28, 629, 2009.

12. BROOMEK J.C., INGELSK C.A. Peach Leaf Curl. University of California Agriculture and Natural Resources. http://www.ipm.ucdavis.edu/PMG/PESTNOTES/pn7426. html. Accessed 12 Sep 2015, 2011.

13. MATYJASZCZYK E. Prevention methods for pest control and their use in Poland. Pest. Manag. Sci., 71 (4), 485, 2015.
14. ŁOZOWICKA B., MICIŃSKI J., ZWIERZCHOWSKI G., KOWALSKI I.M., SZAFAREK J. Monitoring study of pesticide residues in cereals and foodstuff from Poland. Pol. J. Environ. Stud. 21 (6), 1703, 2012.

15. SOBICZEWSKI P., MESZKA B. Current problems of orchards protection against diseases. Bayer Crop Science, 16, 2014 [In Polish].

16. BARTLETT D.W., CLOUGH J.M., GODWIN J.R., HALL A.A., HAMER M., PARR-DOBRZANSKI B. Review - The strobilurin fungicides. Pest Manag. Sci., 58, 649, 2002.

17. SHOLBERG P.L., BEDFORD K., STOKES S. Sensitivity of Penicillium spp. and Botrytis cinerea to pyrimethanil and its control of blue and grey mold of stored apples. Crop Prot., 24, 127, 2005.

18. LEE K.G., LEE S.K. Monitoring and risk assessment of pesticide residues in yuza fruits (Citrus junos Sieb. Ex Tanaka) and yuza tea samples produced in Korea. Food Chem., 135, 2930, 2012.

19. BEMPAH C.K., DONKOR A., YEBOAH P.O., DUBEY B., OSEI-FOSU P. A preliminary assessment of consumer's exposure to organochlorine pesticides in fruits and vegetables and the potential health risk in Accra Metropolis, Ghana. Food Chem., 128, 1058, 2011.

20. FENIK J., TANKIEWICZ M., BIZIUK M. Properties and determination of pesticides in fruits and vegetables. Trend Anal. Chem., 30 (6), 814, 2011.

21. ŁOZOWICKA B., KACZYŃSKI P., JANKOWSKA M., RUTKOWSKA E., HRYNKO I., PARITOWA A. Pesticide residues in raspberries and their risk assessment. Int. Food Res. J., 21 (2), 663, 2014.

22. ŁOZOWICKA B., HRYNKO I., KACZYŃSKI P., RUTKOWSKA E., JANKOWSKA M., MOJSAK P. Occurrence of pesticide residues in fruit from Podlasie (Poland) in 2012. J. Plant Prot. Res., 55 (2), 142, 2015.

23. GEMS/FOOD. Geneva, World Health Organization, http:// who.int/ foodsafety/chem/cluster_diets_2012.pdf. Accessed 08 Mar 2015, 2012.

24. RENWICK A.G. Pesticide residue analysis and its relationship to hazard characterization (ADI/ARfD) and intake estimations (NEDI/NESTI). Pest Manag. Sci., 58, 1073, 2002.

25. ŁOZOWICKA B. Health risk for children and adults consuming apples with pesticide residue. Sci. Total Environ., 502, 184, 2015.

26. ŁOZOWICKA B., KACZYŃSKI P. Determination of carbendazim, linuron and glyphosate residues by HPLC method. Pol. J. Environ. Stud., 18, 100, 2009.

27. Document No. SANCO/12495/2011. Method validation and quality control procedures for pesticide residues analysis in food and feed. http://ec.europa.eu/food/plant/protection/resources/qualcontrol en.pdf. Accessed 12 May 2015, 2012.

28. Document No. SANCO/12571/2013. Guidance document on analytical quality control and validation procedures for pesticide residues analysis in food and feed. http://ec.europa. eu/food/plant/protection/resources/qualcontrol_en.pdf. Accessed 12 May 2015, 2014.

29. GUS. Means of production in agriculture in the 2013/2014 farming year. http://stat.gov.pl/obszary-tematyczne/rolnictwo-lesnictwo/rolnictwo/srodki-produkcji-w-rolnictwie-wroku gospodarczym 2013-2014,6,11.html. Accessed 26 Sep 2015, 2015

30. CRNOGORAC G., SCHMAUDER S., SCHWACK W. Trace analysis of dithiocarbamate fungicide residues on fruits and vegetables by hydrophilic interaction liquid chromatography/tandem mass spectrometry. Rapid Commun. Mass Sp., 22 (16), 2539, 2008. 
31. SZPYRKA E., KURDZIEL A., MATYASZEK A., PODBIELSKA M., RUPAR J., SŁOWIK-BOROWIEC M. Evaluation of pesticide residues in fruits and vegetables from the region of southeastern Poland. Food Control, 48, 137, 2015.

32. BAKIRCI G.T., ACAY D.B.Y., BAKIRCI F., OTLES S. Pesticide residues in fruits and vegetables from the Aegean region, Turkey. Food Chem., 160, 379, 2014.

33. WHO. The WHO recommended classification of pesticides by hazard and guidelines to classification 2009. WHO Technical Report Series 240, Geneva, 2010.

34. OSMAN K.A., AL-HUMAID A.M., AL-REHIAYANI S.M., AL-REDHAIMAN K.N. Monitoring of pesticide residues in vegetables marketed in Al-Qassim region, Saudi Arabia. Ecotox. Environ. Safe, 73, 1433, 2010.

35. ZICARI G., SOARDO V., CERRATO E., RIVETTI D. Results from the monitoring of pesticide residues in fruits and vegetables marketed in Piedmont (Italy), 2000-2008. Igiene e sanita pubblica, 67, 149, 2011.

36. HJORTH K., JOHANSEN K., HOLEN B., ANDERSSON A., CHRISTENSEN H.B., SIIVINEN K., TOOME M.
Pesticide residues in fruits and vegetables from South America - A Nordic project. Food Control, 22, 1701, 2011.

37. WOŁEJKO E., ŁOZOWICKA B., KACZYŃSKI P. Pesticide residues in berries fruits and juices and the potential risk for consumers. Desalin. Water Treat., 52, 3804, 2014.

38. WALORCZYK S. Validation and use of a QuEChERS-based gas chromatographic-tandem mass spectrometric method for multiresidue pesticide analysis in blackcurrants including studies of matrix effects and estimation of measurement uncertainty. Talanta, 120, 106, 2014.

39. SADŁO S., SZPYRKA E., JAŹWAA., ZAWIŚLAK A. Pesticide Residues in Fruit and Vegetables from Southeastern Poland, 2004-05. Polish J. of Environ. Stud. 2, 313, 2007.

40. SZPYRKA E., KURDZIEL A., RUPAR J., SŁOWIKBOROWIEC M. Pesticide residues in fruit and vegetable crops from the Central and Eastern region of Poland. Rocz. Panstw. Zakl. Hig., 66 (2), 107, 2015.

41. Pesticide EU-MRLs Database. htp://ec.europa.eu/sanco pesticides/public/index.cfm. Accessed 08 Mar 2015. 
